\begin{tabular}{|c|c|}
\hline $\begin{array}{l}\text { 2. To: (Receiving organization) } \\
\text { Distribution }\end{array}$ & $\begin{array}{l}\text { 3. From: (originating Organization) } \\
\text { Tank Waste Retrieval and } \\
\text { Disposal }\end{array}$ \\
\hline $\begin{array}{l}\text { 5. Proj./Prog./Dept./Div.: } \\
\text { Waste Feed Del jvery }\end{array}$ & $\begin{array}{l}\text { 6. Design Authority/ Design Agent/Cog. } \\
\text { Engr.: } \\
\text { J. H. Baldwin }\end{array}$ \\
\hline
\end{tabular}

8. Originator Remarks:

\section{Approva1/Release Required}

11. Receiver Remarks: 11A. Design Baseline Docunent? [] Yes [X] No
4. Related EDT No.:

\section{$N / A$}

7. Purchase Order No.:

$$
\mathrm{N} / \mathrm{A}
$$

9. Equip./Component No.: $\mathrm{N} / \mathrm{A}$

10. System/Bldg./Facility: $\mathrm{N} / \mathrm{A}$

12. Major Assm. Dwg. No.: N/A

13. Permit/Permit Application No.: N/A

14. Required Response Date:

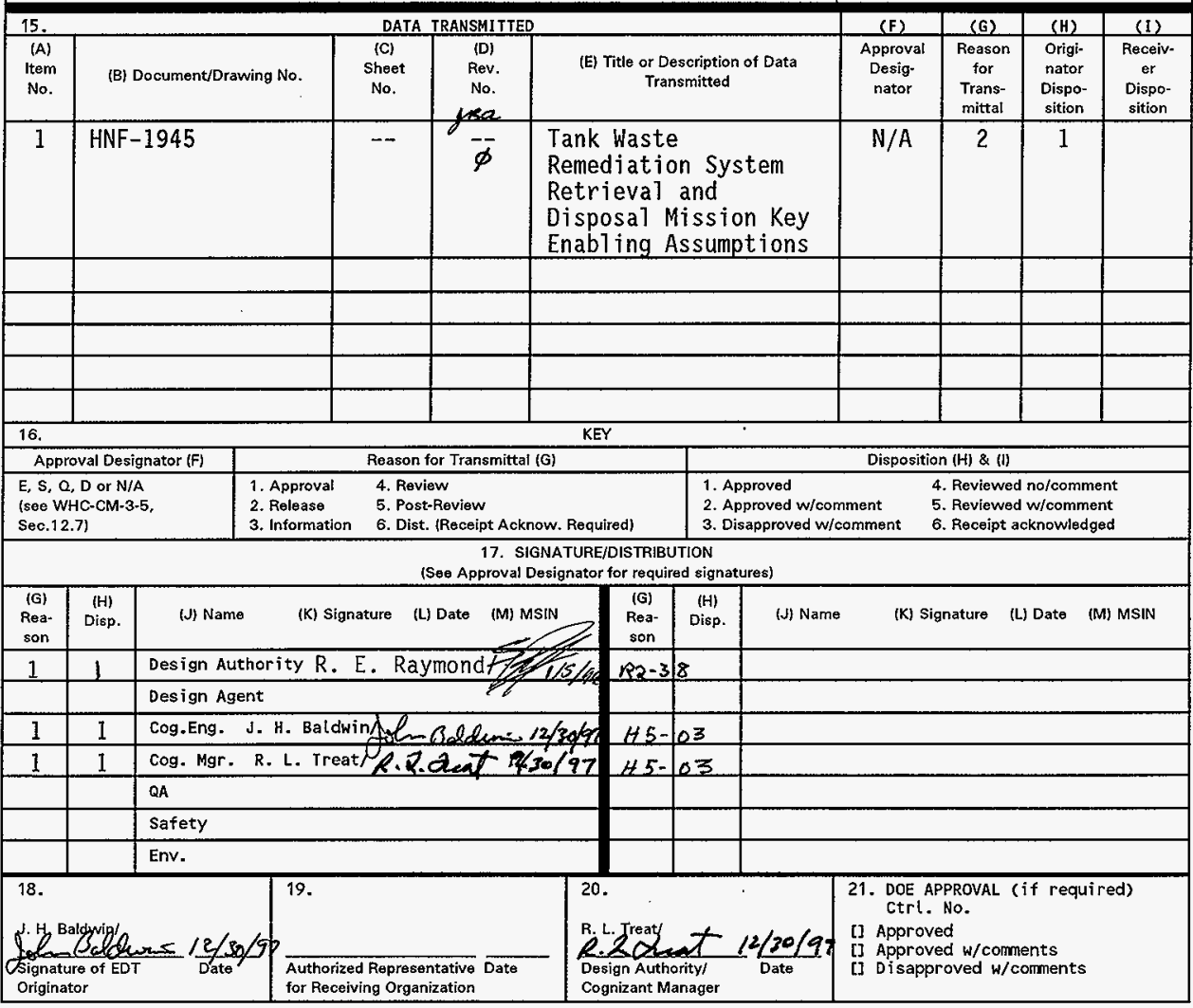


HNF-1945, Rev. O

\title{
Tank Waste Remediation System Retrieval and Disposal Mission Key Enabling Assumptions
}

\author{
J. H. Baldwin \\ Lockheed Marting Hanford Company, Richland, WA 99352 \\ U.S. Department of Energy Contract DE-AC06-96RL13200
}

$\begin{array}{lll}\text { EDT/ECN: } & 609272 & \text { UC: } 2030 \\ \text { Org Code: } & 73600 & \text { Charge Code: } \\ \text { B\&R Code: } & \text { EW3130010 } & \text { Tota1 Pages: } 45\end{array}$

Key Words: TWRS, Retrieval and Disposat Mission, Enabling Assumptions

Abstract: An overall systems approach has been applied to develop action plans to support the retrieval and immobilization waste disposal mission. The review conciuded that the systems and infrastructure required to support the mission are known. Required systems are either in place, or plans have been developed to ensure they exist when needed.

TRADEMARK DISCLAIMER. Reference herein to any specific comercial product, process, or service by trade name, trademark, manufacturer, or otherwise, does not necessarily constitute or imply its endorsement, recommendation, or favoring by the United States Government or any agency thereof or its contractors or subcontractors.

Printed in the United States of America. To obtain copies of this document, contact: WHC/BCS Document Control Services, P.0. Box 1970, Mailstop H6-08, RichlandalA 92352 , Phone $650.92372-2420$. Fax (509) 376-4989.
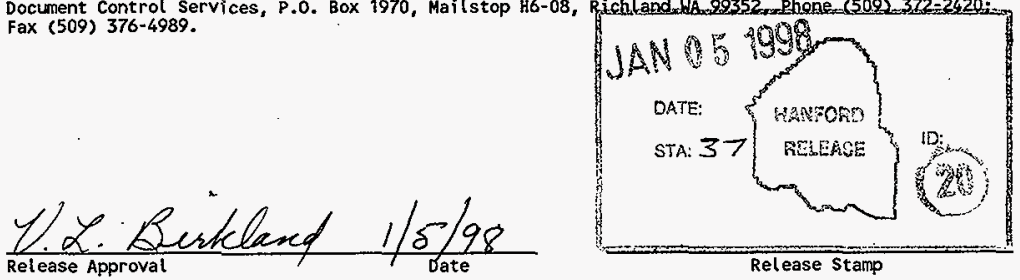
HNF-1945

Revision 0

UC-510

\section{Tank Waste Remediation System Retrieval and Disposal Mission Key Enabling Assumptions}

J. H. Baldwin

Lockheed Martin Hanford Corporation

R. D. Potter

T. J. McLaughlin

R. L. Treat

MACTEC

Date Published

January 1998

Prepared by Lockheed Martin Hanford Corporation

Rrepland, Washington P.S. Department of Energy

Fluor Daniel Hanford, Inc.

P.O. Box 1000

Richland, Washington

Hanford Management and integration Contractor for the

U.S. Department of Energy under Contract DE-AC-0696-RL13200 


\section{LEGAL DISCLAMER}

This report was prepared as an account of work sponsored by an agency of the United States Government. Neither the United States Government nor any agency thereof, nor any of their employees, nor any of their contractors. subcontractors or their employees, makes any warranty, express or implied, or assumes any legal liability or responsibility for the accuracy, completeness, or any third party's use or the results of such use of any information, apparatus, product, or process disclosed, or represents that its use would not infringe privately owned rights. Reference herein to any specific commercial product, process, or service by trade name, trademark, manufacturer, or otherwise, does not necessarily constitute or imply its endorsement, recommendation, or favoring by the United States Government or any agency thereof or its contractors or subcontractors. The views and opinions of authors expressed herein do not necessarily state or reflect those of the United States Government or any agency thereof.

This report has been reproduced from the best available copy.

Available in paper copy and microfiche. 


\section{HNF-1945 Rev 0}

Available to the U.S. Department of Energy

and its contractors from

U.S. Department of Energy

Office of Scientific and Technical

Information (OSTI)

P.O. Box 62

Oak Ridge, TN 37831

(615) $576-8401$

Available to the public from the

U.S. Department of Commerce

National Technical Information Service

(NTIS)

5285 Port Royal Road

Springfield, VA 22161

(703) $487-4650$

Printed in the United States of America

DISCLM-1.CHP (8̣-95) 
HNF-1945 Rev 0

This page intentionally left blank. 
Document Title: $\quad$ Tank Waste Remediation System Retrieval and Disposal Mission Key Enabling Assumptions

Approved by:

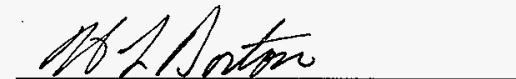

H. L. Boston, Vice President

Tank Waste Retrieval

Lockheed Martin Hanford Corporation
$1 / 5 / 98$

Date 


\section{HNF-1945 Rev 0}

This page intentionally left blank. 
HNF-1945 Rev 0

\section{EXECUTIVE SUMMARY}

An overall systems approach has been applied to develop action plans to support the retrieval and immobilization waste disposal mission. The review concluded that the systems and infrastructure required to support the mission are known. Required systems are either in place or plans have been developed to ensure they exist when needed. The review showed that since October 1996 a rabust system engineering approach to establishing integrated Technical Baselines, work breakdown structures, tank farm structure and configurations and work scope and costs has been established itself as part of the culture within TWRS. An analysis of the programmatic, management and technical activities necessary to declare readiness to proceed with execution of the mission demonstrates that the system, people and hardware will be on line and ready to support the private contractors.

The systems approach included defining the retrieval and immobilized waste disposal mission requirements and evaluating the readiness of the TWRS contractor to supply waste feed to the private contractors in June 2002. The Phase 1 feed delivery requirements from the Private Contractor Request for Proposals were reviewed. Transfer piping routes were mapped out, existing systems were evaluated, and upgrade requirements were defined. Technical Basis Reviews were completed to define work scope in greater detail, cost estimates and associated year by year financial analyses were completed. TWRS personnel training, qualifications, management systems and procedures were reviewed and shown to be in place and ready to support the Phase $1 B$ mission. Key assumptions and risks that could negatively impact mission success were evaluated and appropriate mitigative actions plans were planned and scheduled. 
HNF-1945 Rev 0

An integrated program management plan for the retrieval and disposal mission was developed to describe the overall management approach, organization roles and responsibilities, and overall performance measures.

The primary source of long term and environmental risk results from the continued storage of wastes in the single-shell tank system, which is far beyond its design life, and 67 tanks are presumed to have leaked to this point. A preliminary analysis of enitire feed staging and processing mission to accelerate the removal of waste from the single -shell tanks was conducted. The analysis indicates that the effectiveness and feasibility could be enhanced by extending the Phase 1. contracts, maximizing the capacity deployed with the Phase 1 facilities. This results in a much smaller scale up requirement for the full scale production facilities by allowing a decrease in both the total vitrification plant capacity and peak retrieval requirements to more manageable rates while still meeting the Tri-Party Agreement completion of processing dates.

This systematic review of the PHMC Team's ability to support the retrieval and immobilization waste disposal mission concludes that the systems and infrastructure required to support the mission are understood and in place or plans are in place to ensure they exist when needed. A robust systems engineering culture, management system and risk management program are in place. No technology breakthroughs are needed to achieve a manageable schedule for Phase 1. In short, the review demonstrates that the systems, people and hardware are ready to proceed. 


\section{CONTENTS}

1.0 INTRODUCTION .1

2.0 ENABLING ASSUMPTION MANAGEMENT AND CONTROL SYSTEM $\ldots \ldots \ldots \ldots 1$

3.0 ENABLING ASSUMPTIONS SOURCES $\ldots \ldots \ldots \ldots \ldots \ldots \ldots \ldots \ldots \ldots \ldots \ldots \ldots \ldots$

4.0 PRIORITIZATION OF ENABLING ASSUMPTIONS $\ldots \ldots \ldots \ldots \ldots \ldots \ldots \ldots$

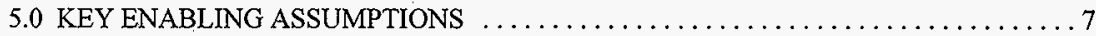

6.0 USE OF THE KEY ENABLING ASSUMPTION DATA SET $\ldots \ldots \ldots \ldots \ldots \ldots \ldots 7$

7.0 INTEGRATION OF TANK WASTE REMEDIATION SYSTEM DATABASES $\ldots \ldots 21$

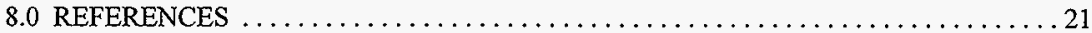

\section{APPENDIX}

A. GUIDANCE AND REQUIREMENTS TO DELIVERABLES CROSSWALK . . . . . . . A-i

\section{LIST OF TABLES}

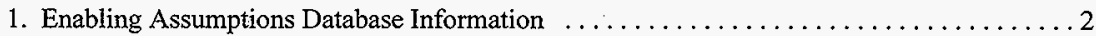

2. Organizations and Sources for Enabling Assumptions $\ldots \ldots \ldots \ldots \ldots \ldots \ldots \ldots, \ldots$

3. Criteria for Setting Enabling Assumption Priorities $\ldots \ldots \ldots \ldots \ldots \ldots \ldots \ldots \ldots$

4. Tank Waste Remediation System Retrieval and Disposal Mission Key

Enabling Assumptions List $\ldots \ldots \ldots \ldots \ldots \ldots \ldots \ldots \ldots \ldots, \ldots \ldots$ 


\section{LIST OF TERMS}

AGA

BIO

CDR

D\&D

DOE

DRD

DST

EA

EAMCS

EIS

FDC

FY

HASP

HLW

ICD

IHLW

ILAW

LAW

LMHC

O\&UP

PC

PHMC

RAM

SEMP

SSC

SST

TWR

TWRS

USQ

WBS
Alternative Generation Analysis

Basis for Interim Operation

conceptual design report

decontamination and decommissioning

U.S. Department of Energy

data requirements document

double-shell tank

enabling assumption

Enabling Assumption Management and Control System

Environmental Impact Statement

functional design criteria

fiscal year

Health and Safety Plan

high-level waste

Interface Control Document

immobilized high-level waste

immobilized low-activity waste

low-activity waste

Lockheed Martin Hanford Corporation

Operation and Utilization Plan

private contractor

Project Hanford Management Contract

reliability, availability, and maintainability

Systems Engineering Management Plan

systems, structures, and components

single-shell tank

Tank Waste Retrieval

Tank Waste Remediation System

unreviewed safety question

Work Breakdown Structure 
HNF-1945 Rev 0

\section{TANK WASTE REMEDIATION SYSTEM RETRIEVAL AND DISPOSAL MISSION KEY ENABLING ASSUMPTIONS}

\subsection{INTRODUCTION}

The Tank Waste Remediation System (TWRS) Project's Retrieval and Disposal Mission must establish and implement the systems, structures, and components necessary to support tank waste retrieval and delivery, immobilized low-activity waste (ILAW) and immobilized highlevel waste (IHLW) storage and disposal, and tank farm closure. The programs have completed and continue to prepare a wide variety of plans, studies, analyses, designs, specifications, schedules, budgets, and other documentation in support of the TWRS Project objectives.

Numerous uncertainties about technical and programmatic issues exist, and many of these uncertainties will not be resolved for months or even years. In order to proceed with its planning efforts, the Retrieval and Disposal Mission programs have made and will continue to make "enabling assumptions" (EA) about the identified uncertainties. Key EAs are those that are key to the success of the Retrieval and Disposal Mission and will be managed and resolved by Retrieval and Disposal Mission management.

This document describes the process that has been used to develop the Key EA list and the system being implemented to document, track, and resolve in an orderly fashion the EAs that are relevant to the Retrieval and Disposal Mission.

\subsection{ENABLING ASSUMPTION MANAGEMENT AND CONTROL SYSTEM}

The Enabling Assumption Management and Control System (EAMCS) was developed to support the Retrieval and Disposal Mission programs' readiness to deliver tank waste feed, store and dispose of ILAW/IHLW and other retained wastes, and close the Tank Farms in accordance with existing schedules and commitments. The EAMCS is the process to ensure an orderly identification, tracking and resolution of EAs. The EAMCS consists of two elements:

- The database of EAs and selected relevant information

- A process, which is the combination of Retrieval and Disposal Mission and TWRS Project procedures that ensure EAs are identified, tracked, and resolved.

The TWRS Technical Database Manager software is a database and modeling tool used by Systems Engineering to develop the TWRS Technical Baseline Database (in the Hanford Site 
Technical Baseline Database [HSTD] using RDD-100 software). The EAs relevant to the Retrieval and Disposal Mission were added to the TWRS Technical Baseline Database to create the EAMCS database (EAMCS). The information captured in the EAMCS database is provided in Table 1.

Table 1. Enabling Assumptions Database Information. (2 Sheets)

\begin{tabular}{|c|c|}
\hline Database element & Description \\
\hline EA number & Unique identifier number. Provides tie to original source. \\
\hline EA title & Brief descriptive title of EA. \\
\hline EA summary & $\begin{array}{l}\text { Provides issue discussion/background/technical basis. Used in conjunction with the } \\
\text { EA title to define the EA. }\end{array}$ \\
\hline Basis for assumption & Provides additional background information to further define the assumption. \\
\hline EA type & $\begin{array}{l}\text { Programmatic or technical. Allows sorting of EAs within RDD-100. Technical EAs } \\
\text { are more likely to result in definitions, requirements, or specifications. }\end{array}$ \\
\hline Priority & $\begin{array}{l}\text { Assigned priority ranking based on risk and other criteria. Lets EAs be managed by } \\
\text { "importance" relative to other EAs. }\end{array}$ \\
\hline Level 1 Logic number & $\begin{array}{l}\text { Associates EA with critical path and other activities identified in the Level } 1 \text { Logic } \\
\text { (not applicable to all EAs). }\end{array}$ \\
\hline $\begin{array}{l}\text { Work Breakdown } \\
\text { Structure (WBS) }\end{array}$ & $\begin{array}{l}\text { Associates EA with WBS number, allowing the EA to be connected to task, } \\
\text { schedule, cost, and other related information within RDD-100. }\end{array}$ \\
\hline Responsible organization & $\begin{array}{l}\text { Primary organization for ensuring the EA is being tracked and resolved. Allows the } \\
\text { EA to be connected to other related information within RDD-100. }\end{array}$ \\
\hline Responsible manager & $\begin{array}{l}\text { Primary manager for ensuring tracking and resolution of the EA occurs. Allows the } \\
\text { EA to be connected to other related information within RDD- } 100 \text {. }\end{array}$ \\
\hline Technical contact(s) & $\begin{array}{l}\text { Person(s) with primary responsibility for achieving EA resolution (into a decision, } \\
\text { fact, criteria, or specification). }\end{array}$ \\
\hline Successor activities & $\begin{array}{l}\text { Impacted organizations/activities/documents. Allows the EA to be connected across } \\
\text { project organizations and to other program activities. }\end{array}$ \\
\hline Actions & $\begin{array}{l}\text { Activities that are required to validate the EA. These may be one or a series of } \\
\text { sequential activities (e.g., trade studies, Alternatives Generation and Analyses) that } \\
\text { need to occur, and may need to be performed by organizations other than the TWRS } \\
\text { Retrieval \& Disposal program (e.g., Nuclear Safety, Characterization). }\end{array}$ \\
\hline Start date & Start date for the next scheduled Action required for validation of the $\mathrm{EA}$. \\
\hline Due date & Date latest scheduled Action must be complete to validate the EA. \\
\hline References & $\begin{array}{l}\text { Source document(s) for EA, impacted documents, validation documents, and other } \\
\text { related materials. }\end{array}$ \\
\hline
\end{tabular}


Table 1. Enabling Assumptions Database Information. (2 Sheets)

\begin{tabular}{|l|l|}
\hline \multicolumn{1}{|c|}{ Database element } & \multicolumn{1}{c|}{ Description } \\
\hline Status comments & $\begin{array}{l}\text { Current status, commentary regarding progress on validating the EA, problems, } \\
\text { creation of new EAs, and other information not captured elsewhere in the database } \\
\text { elements. }\end{array}$ \\
\hline Validation & $\begin{array}{l}\text { Final resolution of EA (into decision, fact, criteria, or specification). Establishes the } \\
\text { final, ending configuration of the EA. }\end{array}$ \\
\hline
\end{tabular}

HSTD, n.d., Hanford Site Technical Baseline Database, database maintained by Lockheed Martin Hanford Corporation for Fluor Daniel Hanford, Inc. Richland, Washington.

$\mathrm{EA}=$ enabling assumption.

WBS $=$ Work Breakdown Structure

RDD-100 = Hanford Site Technical Baseline Database

The EAMCS process is actually the result of a combination of activities conducted within three areas, each of which uses EAs within the Retrieval and Disposal Mission programs. These areas of responsibility include:

- Identifying, accepting, and validating EAs as they arise

- Monitoring the status of given EAs, substantiating or otherwise resolving them, and ensuring that the EAs are replaced with verified information

- Considering and adapting to the potential impacts of EAs on planning (including risk and management planning), scheduling, and budgeting activities.

The practices and activities associated with these areas of responsibility will be described in an implementing guide for the EAMCS which is currently under development.

\subsection{ENABLING ASSUMPTIONS SOURCES}

The Retrieval and Disposal Mission EAS were provided by the organizations and sources listed in Table 2. These sources represent documents and activities that are integral to or associated with tank waste retrieval, delivery, storage, or disposal. 
Table 2. Organizations and Sources for Enabling Assumptions. (2 Sheets)

\begin{tabular}{|c|c|}
\hline Organization & Potentially Applicable Enabling Assumption Source \\
\hline $\begin{array}{l}\text { Systems } \\
\text { Engineering } \\
\text { (TWRS) }\end{array}$ & $\begin{array}{l}\text { - HNF-SD-WM-MAR-008, Tank Waste Remediation System Mission Analysis Reporta } \\
\text { - MHC-SD-WM-SEMP-002, Tank Waste Remediation System Systems Engineering } \\
\text { Management Plan } \\
\text { - HNF-SD-TWR-CSUD-001, TWRS Technical Baseline Database Manager Definition } \\
\text { Document } \\
\text { - WHC-SD-WM-CSUD-012, RDD-100 Users' Guide for TWRS }\end{array}$ \\
\hline $\begin{array}{l}\text { Waste Feed } \\
\text { Delivery (TWRS) }\end{array}$ & $\begin{array}{l}\text { - HNF-SD-TWR-TM-001, Technical Baseline Description of High-Level Waste and } \\
\text { Low-Activity Feed Mobilization and Delivery } \\
\text { - HNF-SD-WM-SP-012, Tank Waste Remediation System Operation and Utilization } \\
\text { Plan } \\
\text { - HNF-1883, Tank Waste Remediation System Program Plan } \\
\text { - HNF-1900, Tank Waste Remediation System Configuration Management Plan }{ }^{\mathrm{b}} \\
\text { - HNF-1881, Tank Waste Remediation System Retrieval and Disposal Mission Waste } \\
\text { Feed Delivery Plan } \\
\text { - RAM Risk Evaluation' }\end{array}$ \\
\hline $\begin{array}{l}\text { Other TWRS } \\
\text { or Organizations }\end{array}$ & $\begin{array}{l}\text { - TBR, AGA, trade studies, CDRs, FDCs, Project Development Specifications, Project } \\
\text { Design Concepts, and DRDs from various "W" projects } \\
\text { - HNF-1882, Tank Waste Remediation System Retrieval and Disposal Mission } \\
\text { Infrastructure Plan" } \\
\text { - HNF-SD-WM-BIO-001, Tank Waste Remediation System Basis for Interim Operation } \\
\text { (BIO)" } \\
\text { - HNF-SD-WM-TSR-006, Tank Waste Remediation System Technical Safety } \\
\text { Requirements" } \\
\text { - HNF-IP-0842, TWRS Administration, Volume IV, "Engineering," Section 5.4, } \\
\text { "Unreviewed Safety Questions"” } \\
\text { - WHC-SD-WM-HSP-002, Tank Farm Health and Safety Plan" }\end{array}$ \\
\hline $\begin{array}{l}\text { Other PHMC } \\
\text { Team members; } \\
\text { Other Hanford Site } \\
\text { Contractors }\end{array}$ & $\begin{array}{l}\text { - HNF-SP-1230, Tank Waste Remediation System Fiscal Year } 1998 \text { Multi-Year Work } \\
\text { Plan WBS 1.1 } \\
\text { - HNF-SD-WM-RPT-294, Decision Document for the Final Disposition of Cesium and } \\
\text { Strontium Capsules } \\
\text { - Various ICDs related to liquid effluents, solid wastes, analytical services environmental } \\
\text { restoration, and infrastructure }\end{array}$ \\
\hline DOE & 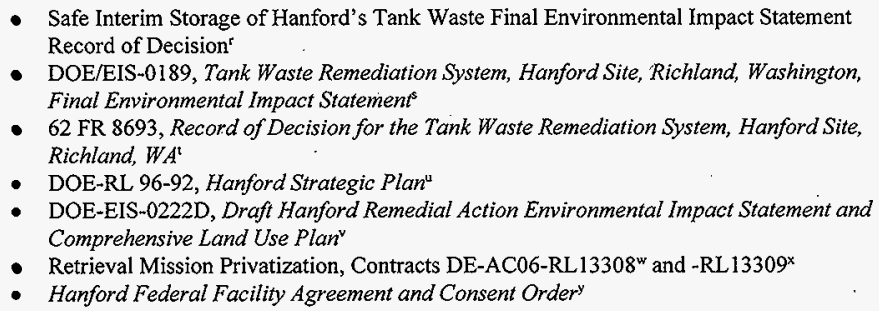 \\
\hline
\end{tabular}


HNF-1945 Rev 0

\section{Table 2. Organizations and Sources for Enabling Assumptions. (2 Sheets)}

"Acree, C. D., Jr, 1998, Tank Waste Remediation System Mission Analysis Report, HNF-SD-WM-MAR-008, Rev. 2, DRAFT, prepared by Lockheed Martin Hanford Corporation for Flour Daniel Hanford, Inc., Richland, Washington.

'Peck, L. G.s, 1998, Tank Waste Remediation System Systems Engineering Management PIan, HNF-SD-WM-SEMP-002, Rev. 1, DRAFT, prepared by Lockheed Martin Hanford Corporation for Flour Daniel Hanford, Inc., Richland, Washington.

'Acree, C. D., Jr., 1997, TWRS Technical Baseline Database Manager Definition Document, HNF-SD-TWR-CSUD-001, Rev. 0, prepared by Lockheed Martin Hanford Corporation for Flour Daniel Hanford, Inc., Richland, Washington.

' Gneiting, B. C., 1996, RDD-100 Users' Guide for TWRS, WHC-SD-WM-CSUD-012, Westinghouse Hanford Company, Richland, Washington.

'Papp, I. G., 1997, Technical Baseline Description of High-Level Waste and Low-Activity Waste Feed Mobilization and Delivery,

HNF-SD-TWR-TM-001, prepared by Numatec Hanford Corporation for Fluor Daniel Hanford, Inc., Richland, Washington.

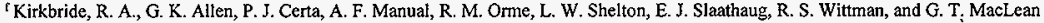
and D. L. Penwell (SESC), 1997, Tank Waste Remediation System Operation and Utilization Plan, HNF-SD-WM-SP-012, Rev. 0, Volumes I and II, prepared by Numatec Hanford Corporation for Fluor Daniel Hanford, Inc., Richland, Washington.

${ }^{8}$ Freeman, D. V., 1998, Tank Waste Remediation System Program Plan, HNF-1883, Rev. 0, DRAFT, prepared by Lockheed Martin Hanford Corporation for Fluor Daniel Hanford, Inc., Richland, Washington.

${ }^{2}$ Vann, J. M., E. R. Hamm, and R. D. Crisp, 1998, Tank Waste Remediation System Configuration Management Plan, HNF-1900, Rev. 0, DRAFT, prepared by Lockheed Martin Hanford Corporation for Fluor Daniel Hanford, Inc., Richland, Washington.

'Potter, R. D., and R. L. Treat, 1998, Tank Waste Remediation System Retrieval and Disposal Mission Waste Feed Delivery Plan, HNF-1881, Rev. 0, DRAFT, prepared by Lockheed Martin Hanford Corporation for Fluor Daniel Hanford, Inc., Richland, Washington.

'Papp, I. G., 1997, Waste Feed Delivery Technical Basis Document, HNF-1939, DRAFT, Vol. III, prepared by Numatec Hanford Corporation for Fluor Daniel Hanford, Inc., Richland, Washington.

${ }^{k}$ Root, R. D., Jr., and R. L. Treat, 1998, Tank Waste Remediation System Retrieval and Disposal Mission Infrastructure Plan, HNF-1882,

Rev. 0, DRAFT, prepared by Lockheed Martin Hanford Corporation for Fluor Daniel Hanford, Inc., Richland, Washington.

' FDH, 1997, Tank Waste Remediation System Basis for Interim Operation, HNF-SD-WM-BlO-001, Rev. 0, Fluor Daniel Hanford, Inc., Richland, Washington.

"Noorani, Y. G., 1997, Tank Waste Remediation Technical Safety Requirements, HNF-SD-WM-TSR-006, Rev. 0, prepared by DE\&S

Hanford, Inc., for Fluor Daniel Hanford, Inc., Richland, Washington.

" LMHC, 1997, TWRS Administration, HNF-IP-0842, Fluor Daniel Hanford, Inc., Richland, Washington.

- Mickle, 1995, Tank Farm Health and Safely Plan, WHC-SD-WM-HSP-002, Rev. 2, Westinghouse Hanford Company, Richland, Washington.

P Lenseigne, D. L., 1997, Tank Waste Remediation System Fiscal Year 1998 Mult-Year Work Plan WBS 1.1, HNF-SP-1230, Rev. 0,

prepared by Lockheed Martin Hanford Corporation for Fluor Daniel Hanford, Inc., Richland, Washington.

${ }^{9}$ Claghorn, R. D., 1997, Decision Document for the Final Disposition for Cesium and Strontium Capsules, HNF-SD-WM-RPT-294, Rev. 0, prepared by Numatec Hanford Corporation for Fluor Daniel Hanford, Inc., Richland, Washington.

'Ecology and RL, 1996, Final Environmental Impact Statement, Safe Interim Storage of Hanford Tank Wastes, DOE/EIS-0212, Washington State Department of Ecology and U.S. Department of Energy, Richlarid Operations Office, Lacey, Washington.

s DOE and Ecology, 1996, Tank Waste Remediation System, Hanford Site, Richland, Washington, Final Environmental Impact Statement, DOE/EIS-0189, U.S. Department of Energy and Washington State Department of Ecology, Washington, D.C.

'62 CFR 8693, 1997, "Record of Decision for the Tank Waste Remediation System, Hanford Site, Richland, WA," Federal Register, Vol. 62 , pp. 8693-8704 (February 26).

" RL, 1996b, Hanford Strategic Plan, DOE/RL 96-92, Rev.0, U.S. Department of Energy, Richland Operations Office, Richland, Washington.

${ }^{*}$ DOE, 1996, Draft Hanford Remedial Action Environmental Impact Statement and Comprehensive Land Use Plan, DOE/EIS-0222D, U.S. Department of Energy, Washington, D. C.

${ }^{*}$ RL, 1996a, British Nuclear Fuels Laboratory Privatization Contract, DE-AC06-96RL13308, U.S. Department of Energy, Richland Operations Office, Richland, Washington.

${ }^{*}$ RL, 1996c, Lockheed Martin Advanced Environmental Systems Privatization Contract; DE-AC06-96RL13309, U.S. Department of Energy, Richland Operations Office, Richland, Washington.

y Ecology, EPA, and DOE, 1996, Hanford Federal Facility Agreement and Consent Order, 2 vols., Washington State Department of Ecology, U.S. Environmental Protection Agency, and U.S. Department of Energy, Olympia, Washington. $A G A=$ alternative generation analysis. $\mathrm{BIO}=$ Basis for Interim Operation $\mathrm{CDR}=$ conceptual design report. $\mathrm{DRD}=$ data requirements document. DOE $=$ U.S. Department of Energy.

EIS = Environmental Impact Statement.

$\mathrm{FDC}=$ functional design criteria.

$F Y=$ fiscal year.

HLW $=$ high-level waste ICD = Interface Control Document. $\mathrm{LAW}=$ low-activity waste.

PHMC = Project Hanford Management Contract.

RAM = reliability, availability, and maintainability.

$\mathrm{TBR}=$ Technical Basis Review.

TWR $=$ Tank Waste Retrieval

TWRS $=$ Tank Waste Remediation System

WBS $=$ Work Breakdown Structure. 


\subsection{PRIORITIZATION OF ENABLING ASSUMPTIONS}

A key element of the EAMCS database is the assignment of a priority to each EA. There are several purposes for prioritizing EAS, such as: allowing senior managers to track missioncritical EAS; highlighting EAS that are time- or cost-critical; and allowing subordinate managers and staff to proceed with EA validation on less critical assumption. A series of priority criteria were established using a four-tier methodology. These criteria incorporate similar logic to that associated with assigning risk, therefore the EA priorities are also consistent with risk-based prioritization schemes. The criteria used to set priorities for EAS are discussed in Table 3.

Table 3. Criteria for Setting Enabling Assumption Priorities. (2 Sheets)

\begin{tabular}{|c|c|c|c|}
\hline Level & Criteria $^{a}$ & Example & $\begin{array}{l}\text { Action } \\
\text { Level }^{\text {b }}\end{array}$ \\
\hline $\begin{array}{c}\text { A } \\
\text { High }\end{array}$ & $\begin{array}{l}\text { 1) EA allows ability to meet } 2002 \text { feed delivery or has } \\
\text { immediate time (e.g., FY } 1998-1999 \text { ) implications. } \\
\text { 2) EA allows initial set of DST retrievals } \\
\text { (e.g., AN-105/AN-104/AW-101). } \\
\text { 3) EA enables PC turnover tanks (AP-106/8). } \\
\text { 4) EA enables feed delivery tanks (AP-102/4). } \\
\text { 5) EA could bottle-neck ability to store PC } \\
\text { ILAW/HLW } \\
\text { 6) EA could have major safety or environmental } \\
\text { impact. } \\
\text { 7) EA could have a major cost impact (e.g., }>\$ 5 \mathrm{M}) \text {. }\end{array}$ & $\begin{array}{l}\text { Tank Farm Operations must } \\
\text { have the personnel resources, } \\
\text { procedures, training, transfer } \\
\text { systems, and priority to } \\
\text { support bootstrap transfers and } \\
\text { emptying (to minimum heel) } \\
\text { of even-numbered AP tanks. }\end{array}$ & 1 \\
\hline $\begin{array}{c}\text { B } \\
\text { Med }\end{array}$ & $\begin{array}{l}\text { 1) EA allows ability to meet feed delivery between } \\
\text { 2005-2011 or has short-term time (e.g., FY 2000- } \\
\text { 2002) impact. } \\
\text { 2) EA affects other initial } 14 \text { DST retrievals (other } \\
\text { than the first 3). } \\
\text { 3) EA could have an environmental, safety, or health } \\
\text { impact. } \\
\text { 4) EA could have a significant cost impact } \\
\text { (e.g., } \$ 0.5-5 \mathrm{M}) \text {. }\end{array}$ & $\begin{array}{l}\text { RAM analysis of Project } \\
W-211 \text { and } W-314 \text { hardware } \\
\text { systems will not result in } \\
\text { significant project delays or } \\
\text { cost increases. }\end{array}$ & 2 \\
\hline $\begin{array}{c}\text { C } \\
\text { Low }\end{array}$ & $\begin{array}{l}\text { 1) EA has longer-term time (e.g., FY 2003-2011) } \\
\text { impact. } \\
\text { 2) EA was limited to document update or other paper } \\
\text { exercise. } \\
\text { 3) EA could have a relatively minor cost implication } \\
\text { (e.g., } \$ 50-100 \mathrm{~K})\end{array}$ & $\begin{array}{l}\text { Retrieval and Disposal Mission } \\
\text { O\&UP must be updated at } \\
\text { least annually. }\end{array}$ & 3 \\
\hline
\end{tabular}


Table 3. Criteria for Setting Enabling Assumption Priorities. (2 Sheets)

\begin{tabular}{|c|c|c|c|}
\hline Level & Criteria $^{a}$ & Example & $\begin{array}{l}\text { Action } \\
\text { Level }^{b}\end{array}$ \\
\hline $\begin{array}{l}\text { D } \\
\text { Very } \\
\text { Low }\end{array}$ & $\begin{array}{l}\text { 1) EA has little or no impacts related to Phase } 1 \text {. } \\
\text { 2) EA has no time implications in Phase } 1 \\
\text { (e.g., }>2012) \text {. } \\
\text { 3) EA could have very little or no cost ( }\langle \$ 50 \mathrm{~K}) \text {, } \\
\text { safety, or environmental implications. }\end{array}$ & $\begin{array}{l}\text { Retrieval of SSTs will be } \\
\text { initiated by } 12 / 03 \text {. Failure to } \\
\text { initiate retrieval on schedule } \\
\text { would compromise the } \\
\text { schedule for turning them over } \\
\text { to EM-40 for D\&D. }\end{array}$ & $\begin{array}{l}\text { Cog. } \\
\text { Eng. }\end{array}$ \\
\hline
\end{tabular}

*Any or all criteria qualify the priority.

${ }^{b}$ Action Level, i.e., PHMC Team management level responsible for management and resolution of the EA.

$D \& D=$ decontamination and decommissioning. ILAW $=$ immobilized low-activity waste.

DST $=$ double-shell tank.

$\mathrm{EA}=$ enabling assumption.

$\mathrm{FY}=$ fiscal year.

IHLW $=$ immobilized high-level waste.

O\&UP = Operation and Utilization Plan.

$\mathrm{PC}=$ private contractor.

RAM $=$ reliability, availability, and maintainability.

SST $=$ single-shell tank.

\subsection{KEY ENABLING ASSUMPTIONS}

Retrieval and Disposal Mission management reviewed the priority A list of EAs and selected and or combined those EAs they felt were most important to the success of the retrieval mission. The resulting list along with the addition of other EAs that are important to management, but not specifically identified in the Retrieval and Disposal Mission program documentation, makes up the Key EA list ( refer to Table 4).

\subsection{USE OF THE KEY ENABLING ASSUMPTION DATA SET}

The EAMCS will be used by the TWRS Project Retrieval and Disposal Mission to effectively manage and control the addition, monitoring and validation of EAs. The EAMCS will provide management a tool to assure that EAs critical to the retrieval mission are tracked and resolved (validated) prior to implementation of the program or process dependent upon their resolution. 


\section{HNF-1945 Rev 0}

This page intentionally left blank. 
Table 4. Tank Waste Remediation System Retrieval and Disposal Mission Key Enabling Assumptions List. (6 sheets)

\begin{tabular}{|c|c|c|c|c|c|}
\hline No. & EA number $^{3}$ & Title & Summary & Basis for assumption & Action to validate/resolve assumption \\
\hline 1 & EAMCS.PG.2.2.2.1 $1^{\mathrm{b}}$ & $\begin{array}{l}\text { PC/TWRS Contractor } \\
\text { Interfaces and Missions }\end{array}$ & $\begin{array}{l}\text { The strategy for waste immobilization will be implemented as described in } \\
\text { the privatization contracts. The specific strategy is as follows. The TWRS } \\
\text { will be responsible for retrieval, infrastructure, preparation, and delivery of } \\
\text { LAW and HLW feed, storage and disposal of waste products for Phase } 1 \text {, } \\
\text { and facility decommissioning of Phase } 1 \text { facilities. PCS will be responsible } \\
\text { for LAW treatment and immobilization, HLW immobilization for Phase } 1 \text {, } \\
\text { and facility deactivation for their Phase } 1 \text { facilities (deactivation, } \\
\text { decommissioning, and decontamination of Phase I facilities and } \\
\text { infrastructures will occur during Phase } 2 \text { ). PCS will be responsible for } \\
\text { waste retrieval, LAW and HLW treatment and immobilization, and facility } \\
\text { decommissioning during Phase } 2 \text {. }\end{array}$ & $\begin{array}{l}\text { The TWRS EIS ROD' selected a phased approach that uses } \\
\text { government and PCS to accomplish the tank waste cleanup mission. } \\
\text { PC contracts and ICDs are the principal guidance documents for } \\
\text { implementing this strategy. }\end{array}$ & $\begin{array}{l}\text { Review copies of the Phase } 1 \text { privatization contracts to } \\
\text { ensure consistency with TWRS PAs, goals, and } \\
\text { capabilities. } \\
\text { Review RL contract award (from } 5 / 29 / 98 \text { ) by } 6 / 30 / 98 \text {. } \\
\text { Review Congressional decision by } 7 / 31 / 98 \text {. }\end{array}$ \\
\hline 2 & EAMCS.SD $.13^{d}$ & $\begin{array}{l}\text { Phase I HLW Interim } \\
\text { Operating Schedule }\end{array}$ & $\begin{array}{l}\text { TWRS program schedule is based on storage availability beginning June } 1 \text {, } \\
2002 \text {. TWRS will deliver the first feed to the PCS in time to support the } \\
\text { June } 2002 \text { startup. }\end{array}$ & $\begin{array}{l}\text { The TWRS EIS ROD' selected a phased approach that uses } \\
\text { government and PCS to accomplish the tank waste cleanup mission. } \\
\text { PC contracts and ICDs are the principal guidance documents that } \\
\text { define when IHLW and ILAW storage are needed. }\end{array}$ & $\begin{array}{l}\text { Request RL to expedite definition of PC need dates for } \\
\text { HLW and LAW feed and for IHLW and ILAW storage. }\end{array}$ \\
\hline 3 & EAMCS.SD. $19^{d}$ & Privatization Schedule & $\begin{array}{l}\text { Privatized hot operations are assumed to start in June } 2002 \text { and end in May } \\
2011 \text {. }\end{array}$ & $\begin{array}{l}\text { The TWRS EIS ROD }{ }^{\circ} \text { selected a phased approach that uses } \\
\text { government and PC to accomplish the tank waste cleanup mission. } \\
\text { PC contracts and ICDs are the principal guidance documents that } \\
\text { define when LAW and HLW feed are needed. }\end{array}$ & $\begin{array}{l}\text { Request RL to expedite definition of PC need dates for } \\
\text { HLW and LAW feed and for IHLW and ILAW storage. }\end{array}$ \\
\hline 4 & $\begin{array}{l}\text { EAMCS.HSEMS. } 23^{\mathrm{e}} \\
\text { EAMCS.PG.2.2.2.7 }\end{array}$ & Phase 1 Schedule & The option to extend Phase 1 will be executed through 2011. & $\begin{array}{l}\text { RL has an option to extend PCS contracts through } 2011 \text {. TWRS } \\
\text { must plan to provide feed to the PC throughout the contract period. }\end{array}$ & $\begin{array}{l}\text { Confirm option period with RL and reconcile to TWRS' } \\
\text { ability to provide feed for the entire duration (the } \\
\text { maximum order quantity issue). }\end{array}$ \\
\hline 5 & EAMCS.150.B.62 & $\begin{array}{l}\text { PC Tank Inspection } \\
\text { Expectations }\end{array}$ & The PC will accept AP-106/8 based on tank integrity guaranteed by RL. & $\begin{array}{l}\text { The PC will take over responsibility for AP-106 and AP-108, } \\
\text { including RCRA' permits. Part of the obligation of being an RCRA } \\
\text { permit signatory is assurance that the tanks are leak-tight. Before } \\
\text { accepting these tanks, the PC may want assurance that RL is } \\
\text { guaranteeing these DSTs meet integrity requirements. RL has } \\
\text { directed that all planning efforts for inspections be stopped. } \text {. }^{\text {h }}\end{array}$ & $\begin{array}{l}\text { Request RL confirm that written guarantees are } \\
\text { acceptable and schedule ensuing actions. }\end{array}$ \\
\hline 6 & $\begin{array}{l}\text { EAMCS.150.B.94 } \\
\text { EAMCS.OUP.5.15 }\end{array}$ & $\begin{array}{l}\text { AP-106/8 Interfaces } \\
\text { Detail }\end{array}$ & $\begin{array}{l}\text { TWRS will relinquish responsibility for operation and maintenance of } \\
\text { AP-106/108 to the PCS in FY } 1999 \text {. Agreements will be negotiated with the } \\
\text { PCS to establish interfaces of operational systems and administrative } \\
\text { controls for the operation of the turned over tanks, including protocols for } \\
\text { entering the AP Tank Farms. These tanks will contain wastes until } \\
\text { bootstrap transfers free up other tank space to accommodate the waste. }\end{array}$ & $\begin{array}{l}\text { The PC will take over responsibilities for AP-106 and AP- } 108 \text {, } \\
\text { including RCRA permits. RL is suggesting a } 6 / 01 \text { turnover date; no } \\
\text { formal direction has been provided. }\end{array}$ & $\begin{array}{l}\text { Make decisions with RL/PCS regarding the safety } \\
\text { authorization basis, environmental permitting, and } \\
\text { administrative protocol issues/interfaces. Make } \\
\text { decision on turnover date: } 3 / 99 \text { or } 6 / 01 \text { or delay } \\
\text { turnover until first batch of waste is delivered into } \\
\text { AP-106/108 (RTP scheduled currently says } 12 / 01 \text { for } \\
\text { turnover). }\end{array}$ \\
\hline 7 & EAMCS. 620.30 & $\begin{array}{l}\text { Feed Delivery and the } \\
\text { USQ Process }\end{array}$ & $\begin{array}{l}\text { The PC will be responsible for USQ evaluations of AP- } 106 / 8 \text { because the } \\
\text { turnover will occur before commencement of PC tank modifications. } \\
\text { TWRS prefers that safety management of AP-106/108 stay within limits } \\
\text { imposed by the TWRS Authorization Basis. }\end{array}$ & $\begin{array}{l}\text { The impacts of new equipment and unanalyzed tank waste on the } \\
\text { current TWRS Authorization Basis are unknown as this time. }\end{array}$ & $\begin{array}{l}\text { Evaluate the proposed waste feed delivery and storage } \\
\text { activities against probable changes to the TWRS } \\
\text { Authorization Basis in a timely manner so that all } \\
\text { planned activities may be completed on schedule. }\end{array}$ \\
\hline 8 & EAMCS.HSEMS.26 $6^{\circ}$ & Final ICDs & $\begin{array}{l}\text { Current ICDs, that define PHMC and PC responsibilities/obligations as they } \\
\text { apply to project interfaces, will not be altered significantly when } \\
\text { incorporated into the Phase } 1 \mathrm{~B} \text { contracts. }\end{array}$ & $\begin{array}{l}\text { ICDs control the customers' and contractors' expectations. Baseline } \\
\text { planning was based on the conditions defined in the draft ICDs. }\end{array}$ & $\begin{array}{l}\text { Reiterate that changes to TWR ICDs will result in } \\
\text { TWRS contractor baseline changes. Monitor progress } \\
\text { in completing ICDs. }\end{array}$ \\
\hline
\end{tabular}


Table 4. Tank Waste Remediation System Retrieval and Disposal Mission Key Enabling Assumptions List. (6 sheets)

\begin{tabular}{|c|c|c|c|c|c|}
\hline No. & EA number ${ }^{\mathrm{a}}$ & Title & Summary & Basis for assumption & Action to validate/resolve assumption \\
\hline 9 & $\begin{array}{l}\text { EAMCS.HSEMS.17 } \\
\text { EAMCS. } 120 . \text { B.65 } \\
\text { EAMCS. } 150 . \text { B. } 24 \\
\text { EAMCS. } 620.10 \\
\text { EAMCS. } 330.20 \\
\text { EAMCS. } 150 . \text { B. } 86 \\
\text { EAMCS. } 150 . \text { B.96 } \\
\text { EAMCS. } 30.80 \\
\text { EAMCS. } 330.90\end{array}$ & $\begin{array}{l}\text { RL Interfaces are } \\
\text { Controlled }\end{array}$ & $\begin{array}{l}\text { Changes in dates, specifications, locations, etc., in the TWRS privatization } \\
\text { RFP may result in changes to scope, cost, and schedule baselines. }\end{array}$ & $\begin{array}{l}\text { Close cooperation and integration among all parties, including RL } \\
\text { oversight activities, are required for mission success. }\end{array}$ & $\begin{array}{l}\text { All parties must review, agree, and commit to the } \\
\text { durations assigned to the technical basis and the logic } \\
\text { activities for which they are responsible. }\end{array}$ \\
\hline 10 & EAMCS.PG.2.2.2.3 & $\begin{array}{l}\text { Budget Validation to } \\
\text { Support PHMC } \\
\text { Responsibilities for All } \\
\text { WDD Projects }\end{array}$ & $\begin{array}{l}\text { Budget validation to support responsibilities for all RL WDD projects will } \\
\text { be achieved in time to support the Phase } 1 \text { schedule. }\end{array}$ & $\begin{array}{l}\text { The normal RL budget validation process may not support early } \\
\text { Phase } 1 \text { activities. The RL FY } 1998 \text { budget may not be sufficient. }\end{array}$ & $\begin{array}{l}\text { Confirm early budget validation for Phase } 1 \text { startup } \\
\text { processes. In association with RL } \\
\text { authorization-to-proceed decision and submit RTP } \\
\text { financial analysis and request for additional funds if } \\
\text { needed. }\end{array}$ \\
\hline 11 & EAMCS.MD.8 & $\begin{array}{l}\text { PC Sampling and } \\
\text { Analysis }\end{array}$ & $\begin{array}{l}\text { Sampling material and analytical scope includes only PHMC requirements } \\
\text { to verify that feed meets the envelope requirements. Sampling requirements } \\
\text { of RL and the PCS are not included in the RTP plan (cost and schedule). }\end{array}$ & $R L$ and $P C$ requirements were undefined during $R T P$ development. & $\begin{array}{l}\text { RL formally define these requirements. Funding and } \\
\text { schedule impacts will be provided by PHMC. }\end{array}$ \\
\hline 12 & $\begin{array}{l}\text { EAMCS.OUP.11.1 } \\
\text { EAMCS.150.B.22 } \\
\text { EAMCS.PG.22.27 }\end{array}$ & $\begin{array}{l}\text { Phase 1 Privatization } \\
\text { Services }\end{array}$ & $\begin{array}{l}\text { The maximum order quantity will be processed. Additional funding will be } \\
\text { provided for W-TBD to allow maximum feed delivery. }\end{array}$ & $\begin{array}{l}\text { TWRS can readily meet minimum and additional PC order quantities } \\
\text { through planned upgrades to DSTs. However, major new project } \\
\text { expenditures are required to provide the maximum order quantity. }\end{array}$ & $\begin{array}{l}\text { Confirm RL acceptance of recommendations from } \\
\text { TWRS O\&UP. Seek additional funding if maximum } \\
\text { order quantities are specified by DOE. }\end{array}$ \\
\hline 13 & EAMCS.MD.9 & $\begin{array}{l}\text { Design and } \\
\text { Authorization Basis } \\
\text { Immobilized Storage }\end{array}$ & $\begin{array}{l}\text { The CSB (IHLW) is assumed to be a modification of the SFP Authorization } \\
\text { Basis. The vault modifications (ILAW) will require a separate } \\
\text { Authorization Basis. }\end{array}$ & $\begin{array}{l}\text { The CSB is an extension of the SFP (vault 1) Authorization Basis. } \\
\text { Vaults for disposal of ILAW will be a separate Authorization Basis } \\
\text { due to significant differences from tanks Authorization Basis. }\end{array}$ & $\begin{array}{l}\text { CSB integrated planning will validate this assumption } \\
\text { via an approved permitting plan. Vault integrated } \\
\text { planning will validate this assumption via an approved } \\
\text { permitting plan. }\end{array}$ \\
\hline 14 & EAMCS.MD.1 & $\begin{array}{l}\text { 241-AY-102 Retrieval } \\
\text { (HLW) Project } \\
\text { Acceleration }\end{array}$ & $\begin{array}{l}\text { Funding will be made available to accelerate Project W-211 to meet the } \\
\text { need date for AY-102. } \\
\text { Currently planned for } 6 / 03 \text {. }\end{array}$ & $\begin{array}{l}\text { Change to the Project W-211 schedule is required to satisfy waste } \\
\text { feed delivery schedule. }\end{array}$ & $\begin{array}{l}\text { Rebaseline the W-211 schedule and develop a new } \\
\text { schedule and funding profile. Include 2-year funding } \\
\text { cycle in schedule. }\end{array}$ \\
\hline 15 & EAMCS.MD. 2 & Air Permits & $\begin{array}{l}\text { RL, will provide funding for additional WDOH and Ecology personnel to } \\
\text { process Phase } 1 \mathrm{~B} \text { Clean Air Act }{ }^{j} \text { permits in a timely manner. }\end{array}$ & $\begin{array}{l}\text { WDOH and Ecology require permit fees or equivalent support funds } \\
\text { to process radioactive air and toxic Clean Air Aci permits, } \\
\text { respectively. As currently budgeted, neither agency has sufficient } \\
\text { processing funds; they therefore will not be able to issue permits to } \\
\text { RL that will support Phase } 1 \text { activity schedules. }\end{array}$ & $\begin{array}{l}\text { Formally encourage the funding of these permit } \\
\text { processing budgets with } \mathrm{RL} \text {. }\end{array}$ \\
\hline 16 & EAMCS.HCEMS. $14^{\circ}$ & $\begin{array}{l}\text { Expanded Line Item } \\
\text { Projects }\end{array}$ & $\begin{array}{l}\text { DSTs that must be retrieved to meet maximum order quantities but are not } \\
\text { included in the scopes of Projects W-211 and W- } 314 \text { will be covered } \\
\text { through change orders and/or a new line item project(s), e.g., W-TBD. }\end{array}$ & $\begin{array}{l}\text { Projects W-211 and W-314 are the principal line item projects that } \\
\text { will upgrade existing DSTs to support TWRS privatization. With full } \\
\text { implementation of these projects, retrieval of the first } \sim 10 \text { DSTs can } \\
\text { succeed. To complete maximum delivery orders, an additional } \\
\text { project or changes to Projects W-211/W-314 will be required. }\end{array}$ & $\begin{array}{l}\text { Confirm that waste feed delivery capability is consistent } \\
\text { with RL objectives. }\end{array}$ \\
\hline
\end{tabular}


Table 4. Tank Waste Remediation System Retrieval and Disposal Mission Key Enabling Assumptions List. (6 sheets)

\begin{tabular}{|c|c|c|c|c|c|}
\hline No. & EA number ${ }^{A}$ & Title & Summary & Basis for assumption & Action to validate/resolve assumption \\
\hline 17 & EAMCS.MD. 3 & Regulatory Authority & $\begin{array}{l}\text { Technical and budget planning are based on safety regulations consistent } \\
\text { with DOE requirements since NRC requirements are unknown at this time. }\end{array}$ & $\begin{array}{l}\text { The NRC regulates commercial HLW. OCRWM may open a } \\
\text { geologic disposal repository near Las Vegas in } \sim 2010 \text {. Except for } \\
\text { the Basalt Waste Isolation Project, NRC has not considered the } \\
\text { Hanford Site as a licensee. Regulating tank residuals as HLW would } \\
\text { add years of regulatory burden to the TWRS project and result in } \\
\text { added expenditures. }\end{array}$ & $\begin{array}{l}\text { The NRC's preliminary finding establishes a provisional } \\
\text { agreement that the LAW portion of the Site tank waste } \\
\text { planned for removal from the tanks and disposal on site } \\
\text { is incidental waste and, therefore, not subject to NRC } \\
\text { licensing authority.' } \\
\text { COMPLETED }\end{array}$ \\
\hline 18 & EAMCS.MD. 4 & $\begin{array}{l}\text { Design and } \\
\text { Authorization Basis }\end{array}$ & $\begin{array}{l}\text { Current design choices (in safety class designations) will not change as the } \\
\text { Authorization Basis is approved. }\end{array}$ & Planned retrieval is an extension of current operations. & $\begin{array}{l}\text { The proposed feed delivery activities must be evaluated } \\
\text { against probable changes to the TWRS Authorization } \\
\text { Basis in a timely manner so that all planned activities } \\
\text { may be completed on schedule. }\end{array}$ \\
\hline 19 & EAMCS.MAR. $1^{1}$ & $\begin{array}{l}\text { Tank Waste } \\
\text { Classification }\end{array}$ & $\begin{array}{l}\text { Federal regulations require that HLW be disposed in NRC-licensed } \\
\text { facilities. Tank wastes must be classified as non-HLW to be exempt from } \\
\text { disposal in an NRC-licensed disposal facility. The NRC will classify } \\
\text { residual waste remaining in tank farms after retrieval as non-HLW. } \\
\text { Technical bases for classifying portions of the waste as non-HLW will be } \\
\text { developed in accordance with the NRC criteria. Discussions with NRC and } \\
\text { stakeholders will be held and NRC concurrence will be requested. }\end{array}$ & $\begin{array}{l}\text { Commercial HLW is regulated by the NRC. RL OCRWM may open } \\
\text { a geologic disposal repository near Las Vegas in } 2010 \text {. Except for } \\
\text { the Basalt Waste Isolation Project, NRC has not considered the } \\
\text { Hanford Site as a licensee. Regulating tank residuals as HLW would } \\
\text { add years of regulatory burden to the TWRS project and result in } \\
\text { unnecessary expenditures. }\end{array}$ & $\begin{array}{l}\text { The NRC's preliminary finding establishes a provisional } \\
\text { agreement that the LAW portion of the Site tank waste } \\
\text { planned for removal from the tanks and disposal on site } \\
\text { is incidental waste and, therefore, not subject to NRC } \\
\text { licensing authority. } \\
\text { COMPLETED }\end{array}$ \\
\hline 20 & EAMCS.MAR.2' & $\begin{array}{l}\text { DST Radionuclide } \\
\text { Content }\end{array}$ & $\begin{array}{l}\text { Radionuclide content which can remain in the treated LAW fraction from } \\
\text { SSTs and DSTs and which allows onsite disposal and exemption from NRC } \\
\text { regulatory jurisdiction has not been defined. The residual waste after } \\
\text { treatment is considered incidental waste based on the NRC's previous ruling } \\
\text { for DST wastes. }\end{array}$ & $\begin{array}{l}\text { Commercial HLW is regulated by the NRC. RL OCRWM may open } \\
\text { a geologic disposal. repository near Las Vegas in } \sim 2010 \text {. Except for } \\
\text { the Basalt Waste Isolation Project, NRC has not considered the } \\
\text { Hanford Site as a licensee. Regulating tank residuals as HLW would } \\
\text { add years of regulatory burden to the TWRS project and result in } \\
\text { unnecessary expenditures. }\end{array}$ & $\begin{array}{l}\text { The NRC's preliminary finding establishes a provisional } \\
\text { agreement that the LAW portion of the Site tank waste } \\
\text { planned for removal from the tanks and disposal on site } \\
\text { is incidental waste and, therefore, not subject to NRC } \\
\text { licensing authority. } \\
\text { COMPLETED }\end{array}$ \\
\hline 21 & $\begin{array}{l}\text { EAMCS. } 150 . \text { B. } 10 \\
\text { EAMCS.250.4.E.0 } \\
\text { EAMCS.250.4.G.0 } \\
\text { EAMCS.MYWP. } 3^{m}\end{array}$ & $\begin{array}{l}\text { Safety Analysis and } \\
\text { Evaluation/AB } \\
\text { Amendments }\end{array}$ & $\begin{array}{l}\text { Technical issues will be resolved in a manner which will support approval } \\
\text { of any required Authorization Basis amendment on schedule. }\end{array}$ & $\begin{array}{l}\text { The TWRS BIOn was recently issued. All departures from the BIO } \\
\text { require an Authorization Basis amendment. }\end{array}$ & $\begin{array}{l}\text { Identify all necessary Phase } 1 \text { Authorization Basis } \\
\text { amendment documentation needs as soon as possible. }\end{array}$ \\
\hline 22 & $\begin{array}{l}\text { EAMCS.SD. } 20^{d} \\
\text { EAMCS.SD. } 21^{d} \\
\text { EAMCS.SD. } 22^{d}\end{array}$ & Onsite Disposal of ILAW & $\begin{array}{l}\text { Vaults can be used for disposal of ILAW after: (1) confirmation by PAs; } \\
\text { (2) confirmation that NRC criteria have been met; and (3) RL-HQ disposal } \\
\text { authorization. }\end{array}$ & $\begin{array}{l}\text { Existing grout vaults are being modified for disposal of ILAW. The } \\
\text { ILAW can be disposed in the modified grout vaults after reviews and } \\
\text { approvals by NRC and DOE-HQ. Onsite disposal of ILAW without } \\
\text { NRC licensing is consistent with guidance from RL and NEPA } \\
\text { documentation. The NRC has determined that Hanford Site tank } \\
\text { waste can be classified as incidental waste and is not subject to NRC } \\
\text { regulation provided these criteria are met: } \\
\text { 1. The waste meets the concentration limits in } 10 \text { CFR } 61.55^{p} \\
\text { 2. Radionuclides are removed to the extent technically and } \\
\text { 3. Puomically practical } \\
\text { Public health is protected consistent with } 10 \text { CFR } 61 . p\end{array}$ & $\begin{array}{l}\text { Complete PA and DOE-HQ reviews. Provide input for } \\
\text { DOE-HQ briefing to NRC on results. }\end{array}$ \\
\hline
\end{tabular}


Table 4. Tank Waste Remediation System Retrieval and Disposal Mission Key Enabling Assumptions List. (6 sheets)

\begin{tabular}{|c|c|c|c|}
\hline No. & EA number ${ }^{2}$ & Title & Summary \\
\hline 23 & $\begin{array}{l}\text { EAMCS. } 130 . \text { B. } 17 \\
\text { EAMCS.130.B20 } \\
\text { EAMCS.OUP. } 1.4^{i} \\
\text { EAMCS.OUP. } 3.2^{i}\end{array}$ & $\begin{array}{l}\text { Flammable Gas Watch } \\
\text { List DSTs }\end{array}$ & $\begin{array}{l}\text { DOE Secretarial/Congressional approval will be obtained in a timely } \\
\text { manner to add diluents, mix, and retrieve } 241-A N-105,241 \text {-AN-104, } \\
\text { 241-AN-103, AW-101, SY-103, and 241-SY-101 currently on the } \\
\text { Flammable Gas Watch List. }\end{array}$ \\
\hline 24 & EAMCS.OUP.1.4 & Tri-Party Agreement & $\begin{array}{l}\text { The Tri-Party Agreement } \text { schedule for SST retrieval will be renegotiated to } \\
\text { support Phase } 1 \text { fuel delivery. }\end{array}$ \\
\hline 25 & $\begin{array}{l}\text { EAMCS.MYWP. } 38^{\mathrm{m}} \\
\text { EAMCS.CLO. } 12^{\mathrm{s}}\end{array}$ & Continuous Use of DSTs & $\begin{array}{l}\text { DSTs space availability required to execute the Phase } 1 \text { mission will be } \\
\text { consistent with planning assumptions in the TWRS O\&UP. }\end{array}$ \\
\hline 26 & $\begin{array}{l}\text { EAMCS.MD.5 } \\
\text { EAMCS.350.X05 }\end{array}$ & Separated Solids Return & $\begin{array}{l}\text { PC-returned separated solids will be at the rate of approximately two } 8,000- \\
\text { gal transfers per LAW plant per year. The LAW plant solids return streams } \\
\text { meet acceptance and compatibility criteria necessary to make a transfer to } \\
\text { AP-107. The PC provides analysis data which supports performance of } \\
\text { these transfers. Tank farm operations controls these transfers. }\end{array}$ \\
\hline 27 & $\begin{array}{l}\text { EAMCS.CLO. } 10^{\circ} \\
\text { EAMCS. } 160 . \text { A26 } \\
\text { EAMCS. } 160 . \text { A52 }\end{array}$ & $\begin{array}{l}\text { Enhanced Sludge } \\
\text { Washing Capability }\end{array}$ & $\begin{array}{l}\text { TWRS will have the capability to successfully perform enhanced in-tank } \\
\text { sludge washing. The sludge in HLW tanks will be washed in three cycles } \\
\text { using a caustic/water mix. }\end{array}$ \\
\hline 28 & EAMCS. 130. B. 40 & $\begin{array}{l}\text { Perform Bootstrap } \\
\text { Transfers to Empty and } \\
\text { Flush Out } 241-A P-102 \\
-104,-106 \text {, and }-108\end{array}$ & $\begin{array}{l}\text { Emptying of AP-102/4/6/8 DSTs via bootstrap transfers will be executed as } \\
\text { planned. }\end{array}$ \\
\hline 29 & $\begin{array}{l}\text { EAMCS.CLO. } 16^{5} \\
\text { EAMCS.HSEMS. } 12^{\circ} \\
\text { EAMCS.MYWP. } 37^{\mathrm{m}}\end{array}$ & $\begin{array}{l}\text { 242-A Evaporator } \\
\text { Availability }\end{array}$ & $\begin{array}{l}\text { The 242-A Evaporator will be available to support waste processing } \\
\text { operations until the Phase } 2 \text { LAW immobilization facility is in operation. } \\
\text { All upgrades necessary to extend the operation of the evaporator through } \\
\text { FY } 2011 \text { will be completed by FY } 2005 \text {. }\end{array}$ \\
\hline 30 & $\begin{array}{l}\text { EAMCS.120.C. } 10 \\
\text { EAMCS. } 110.45 \\
\text { EAMCS. } 160 . \text { A52 }\end{array}$ & $\begin{array}{l}\text { Mixing \& Retrieval } \\
\text { System }\end{array}$ & $\begin{array}{l}\text { Large mixer pumps will be successful in DST retrieval based on mixer tests } \\
\text { (Project W-151) to be conducted in tank AZ-101. Project W-151 will } \\
\text { provide test results indicating the TWRS O\&UPs model for HLW washing, } \\
\text { settling, and sampling is valid. }\end{array}$ \\
\hline
\end{tabular}

Wastes currently in six Flammable Gas Watch List tanks are expected to fit envelope criteria and are planned to be retrieved during Phase I. Retrieval of the waste ( $280 \%$ of volume) from the tanks supports the technical basis for removal of the tanks from the watch list. Also, the retrieved diluted waste will not cause staging/feed tanks to become Watch List Tanks.

The Tri-Party Agreementa milestones for SST waste removal are inconsistent with current budget planning for Phase 1. DST space initations prevent achieving all Tri-Party Agreement ${ }^{t}$ objectives regarding SST retrieval.

Because of the limited available DST space, and the need to support storage of new wastes, much of the new tank space created by retrieval will be needed to provide flexibility and reduce risk of failure to deliver feed.

Return transfers to TWRS must meet the TWRS Authorization Basis and because of tank space limitations, must be received into a single tank, AP-107. Transfer system is administratively restricted to onc ransfer into AP-107 at a time. If a line plugs, both LAW plants would be impacted.

Enhanced sludge washing is required to reduce the concentration of certain constituents to meet the Envelope D limits.

Four AP tanks must be emptied for use as feed tanks by the PCS and TWRS. Bootstrap transfers and the use of the 242-A Evaporator are required to support this action. Limited tank space exists to accommodate the waste from emptied tanks.

242-A Evaporator operation is required to maximize the availability f DST volume for storage of newly generated wastes. Because of he age of the evaporator, upgrades to extend its life will be

State-of-the-art 300-hp pumps will be used to homogenize DST astes. Similar pumps have been successful at Savannah River and West Valley, but have experienced periodic failures.
Action to validate/resolve assumption Provide schedule for waste retrieval to $\mathrm{RL}$ indicating critical need dates for approval to add diluents, mix, and retrieve waste from watch list tanks and provide potential cost and schedule impacts due to failure to receive approval.

Obtain agreement with RL and other Tri-Party Agreement ${ }^{4}$ signatories on changes to the milestones

Define needed available volume and identify preferred tanks to provide processing flexibility and lower risk.

Reiterate this limitation to RL. Negotiate this with the PC and reflect in ICDs. Suggest alternative to lower the risk: (1) pump LAW solids directly to the HLW plant, or (2) have PC extend its return line directly to AP-107 so that the two plants can transfer independent from each other.

Confirm the process to meet Envelope D limits and perform early laboratory tests with representative fre washed) in the Project W-151 mixer pump demonstration. Specify the necessary

upgrades to complete caustic addition in AZ-101/102 and $\mathrm{AY} Y-102$.

Maintain evaporator operational readiness and tank space avallability necessary to support bootstrap transfers.

Implement projects to upgrade the 242-A Evaporato and ensure that the evaporator will support early PHMC Mult-Year Program Plan.

Confirm mixer pump technology is appropriate for retrieving DSTs via mixer tests, etc. (W-151) 
Table 4. Tank Waste Remediation System Retrieval and Disposal Mission Key Enabling Assumptions List. (6 sheets)

\begin{tabular}{|c|c|c|c|c|c|}
\hline No. & EA number ${ }^{a}$ & Title & Summary & Basis for assumption & Action to validate/resolve assumption \\
\hline 31 & $\begin{array}{l}\text { EAMCS.HSEMS.24 } \\
\text { EAMCS.440.50 } \\
\text { EAMCS.SD.3 } \\
\text { EAMCS.SD.5 } \\
\text { EAMCS.SD.7 } \\
\text { EAMCS.SD.15 } \\
\text { EAMCS.SD. } 17 \\
\text { EAMCS.SD. } 23\end{array}$ & $\begin{array}{l}\text { ILAW and IHLW } \\
\text { Volumes }\end{array}$ & $\begin{array}{l}\text { Assumed HLW and LAW inmobilized waste volumes contained in the } \\
\text { TWRS O\&UP' in compliance with the privatization contract will be the } \\
\text { actual attained volume used in the final Phase } 1 \text { contracts. }\end{array}$ & $\begin{array}{l}\text { ILAW and HHLW volumes will drive space requirements in vaults } \\
\text { and the Canister Storage Building. }\end{array}$ & $\begin{array}{l}\text { Confirm program plans and capabilities, including PC's } \\
\text { projected waste loadings in glass and canister filling } \\
\text { efficiency. }\end{array}$ \\
\hline 32 & $\begin{array}{l}\text { EAMCS. } 360.80 \\
\text { EAMCS.360.90 } \\
\text { EAMCS.OUP.4. } 6^{i} \\
\text { EAMCS.OUP. } .7^{i}\end{array}$ & $\begin{array}{l}\text { PC HLW Feed Tank } \\
\text { Design, Feed } \\
\text { Composition and } \\
\text { Immobilization Rate }\end{array}$ & $\begin{array}{l}\text { HLW immobilization rate will be } 60 \mathrm{MT} \text { waste oxides excluding silicon and } \\
\text { sodium per year. The PCS will have sufficient storage capacity to receive } \\
2155,000 \mathrm{gal} \text { of } \mathrm{HLW} \text { feed and will immobilize one transfer every } 6 \text { to } \\
9 \text { months. The HLW PC will design its HLW receipt tank to contain } 5 \mathrm{MT} \\
\text { waste oxides excluding silicon and sodium at a total waste oxide loading of } \\
25 \mathrm{~g} / \mathrm{L} \text {. The waste batch will be transferred at } 100 \mathrm{~g} / \mathrm{L} \text {. }\end{array}$ & $\begin{array}{l}\text { Given current tank space and operating constraints, TWRS requires } \\
\text { the PC to have tanks sufficiently large to avoid the need for frequent } \\
\text { transfers of HLW. }\end{array}$ & $\begin{array}{l}\text { Communicate this concern to RL well before the } \\
\text { Phase } 1 \text { PC contracts are completed and get this } \\
\text { assumption validated. }\end{array}$ \\
\hline 33 & EAMCS.OUP.6.1 ${ }^{\mathrm{i}}$ & Facility Processing Rates & $\begin{array}{l}\text { The processing rate for each facility during Phase } 1 \text { is } 2.0 \mathrm{MT} \mathrm{Na} \text { /day } \\
\text { (LAW) for both PCS and } 0.164 \text { MT NVOL/day (HLW) for the HLW PC. }\end{array}$ & $\begin{array}{l}\text { LMHC has determined that PC process rates in excess of these will } \\
\text { result in an inability to supply feed on demand. }\end{array}$ & $\begin{array}{l}\text { 1. Ensure that RL is aware of this planning basis. } \\
\text { 2. Evaluate options if rates are higher. }\end{array}$ \\
\hline 34 & EAMCS.120.D.40 & $\begin{array}{l}\text { Tank AN-105 as First } \\
\text { Batch of LAW. }\end{array}$ & $\begin{array}{l}\text { Tank AN-105 is acceptable as the source tank for the first batch of LAW. } \\
\text { The envelope A specification limit will be changed to } 0.5 \text { mole TOC/mole } \\
\text { Na. }\end{array}$ & $\begin{array}{l}\text { Several of the first tanks to be retrieved are on the Flammable Gas } \\
\text { Watch List and were chosen because their waste composition is } \\
\text { closely aligned to Envelope A requirements, with the exception of } \\
\text { TOC. }\end{array}$ & $\begin{array}{l}\text { Proceed as documented in plans, including in-tank DQO } \\
\text { confirmation process. }\end{array}$ \\
\hline 35 & $\begin{array}{l}\text { EAMCS.MYWP. } 27^{\mathrm{m}} \\
\text { EAMCS.OUP. } 3.2^{\mathrm{i}}\end{array}$ & $\begin{array}{l}\text { Co-Mingling of Wastes } \\
\text { in DSTs During Pumping }\end{array}$ & $\begin{array}{l}\text { Wastes will be co-mingled during pumping. Compatibility studies will be } \\
\text { performed to ensure that there are no adverse chemical reactions. RL will } \\
\text { accept the potential cost of contaminating non-complexed wastes with } \\
\text { organics/complexed wastes. }\end{array}$ & $\begin{array}{l}\text { Because of the limited available DST space, individual tanks must } \\
\text { be emptied and filled many times. To meet the RL-prescribed } \\
\text { envelope specifications, wastes from multiple sources may be mixed } \\
\text { in the same DST. Inability to remove all waste from the tanks } \\
\text { results in a heel that will become mixed with newly added waste. }\end{array}$ & $\begin{array}{l}\text { Communicate plans to co-mingle wastes in DSTs to RL } \\
\text { and ensure that compatibility tests are performed. } \\
\text { Require RL's concurrence with our feed delivery plans. }\end{array}$ \\
\hline 36 & EAMCS.MD.7 & $\begin{array}{l}\text { Qualify Feed in Source } \\
\text { Tank }\end{array}$ & $\begin{array}{l}\text { Qualification of some feed material provided to } \mathrm{PC} \text { will be conducted in the } \\
\text { source tanks for certain batches, not the staging tanks (AN-102/104). }\end{array}$ & $\begin{array}{l}\text { After delivery of small batches of feed, and to avoid idle time of the } \\
\text { PC facilities, the next batch may need to be qualified in the source } \\
\text { tank to minimize the delivery time. }\end{array}$ & $\begin{array}{l}\text { Confirm with RL that feed qualification in the source } \\
\text { tank is acceptable. Develop optional work-around to } \\
\text { avoid PC facility idle time. }\end{array}$ \\
\hline
\end{tabular}


Table 4. Tank Waste Remediation System Retrieval and Disposal Mission Key Enabling Assumptions List. (6 sheets)

\begin{tabular}{|c|c|c|c|c|c|}
\hline No. & EA number ${ }^{2}$ & Title & Summary & Basis for assumption & Action to validate/resolve assumption \\
\hline 37 & EAMCS.OUP.5.4 & $\begin{array}{l}\text { LAW Waste Transfer } \\
\text { Schedule }\end{array}$ & $\begin{array}{l}\text { The waste transfer date (the date at which the PC requests delivery of new } \\
\text { feed from TWRS) will be (1) before the date on which } 30 \text { days of feed at the } \\
\text { PC's processing rate remains in the PC's feed tank and ( } 2 \text { ) not before the } \\
\text { allowed period of time between feed delivery cycles has elapsed. These } \\
\text { periods of time will be established as part of the PC Phase } 1 \text { contracts or } \\
\text { other agreement, and will be based on TWRS' projected ability to deliver } \\
\text { individual batches of feed of various volumes and sodium contents to the } \\
\text { PCS. If previously qualified feed remains in the TWRS staging tank after } \\
\text { delivery of feed occurs, TWRS will have the authority to transfer the } \\
\text { remnants (top-off transfer) as soon as sufficient space in the PC's tank is } \\
\text { created. The PC will empty its feed tank to the limits of the removal } \\
\text { capacity of the installed pump (minimum heel) before switching to a new } \\
\text { envelope. }\end{array}$ & $\begin{array}{l}\text { The allotted time to complete a delivery of feed is } 30 \text { days. This } \\
\text { allows for the time for pumping and to recover from potential } \\
\text { equipment failures. The allowed frequency of requesting new feed } \\
\text { must be matched to TWR's delivery capability which is impacted } \\
\text { by batch volume and sodium content. }\end{array}$ & $\begin{array}{l}\text { Communicate this concern to RL well before Phase } 1 \\
\text { PC contracts are completed. Ensure appropriate } \\
\text { limiting conditions are imposed in the Phase } 1 \mathrm{~B} \\
\text { contracts. }\end{array}$ \\
\hline
\end{tabular}

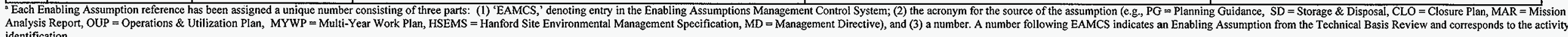

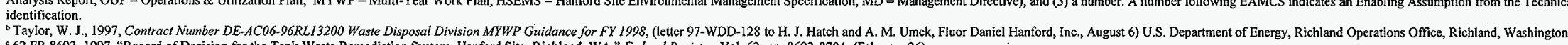
: 62 FR 8693, 1997, "Record of Decision for the Tank Waste Remediation System, Hanford Site, Richland, WA," Federal Register, Vol. 62, pp. 8693-8704, (February 26). ¿Calmus, R. B., 1996, Design Requirements Document for Intern Shage Phase I Solidififcation of Hight:Level Waste, WHC-SD-WM-DRD-012, Westinghouse Hanford Company, Richland, Washington

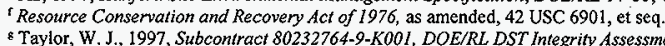

8 Taylor, W. J., 1997, Subcontract 80232764-9-K00I, DOE/RL DST Integrity Assessment Work Planning, (letter 97-WSD-232 to H. J. Hatch and A. M. Umek, Fluor Daniel Hanford, Inc., October 30) U.S. Department of Energy, Richland Operations Office, Richland, Washington

"Umek, A. M., and D. S. Rewinkle, 1997, Subcontract $80232764-9$-K001, DOE/RL DST Integrity Assessment Work Planning, (letter 9760373A to L. E. Hall, Lockheed Martin Hanford Corporation, November 25) Fluor Daniel Hanford, Inc., Richland, Washington,

Washington.
iClean Air Act of 1977 , as amended, 42 U.S.C 7401 , et seq.

${ }^{k}$ Kinzer, J. E., 1997, Contract Number DE-ACO6-96RLL13200; Tank Waste Remediation System (TWRS) System Requirements Review Action Plan (lenter 96-TWR-025 to H.J. Hatch, Fluor Daniel Hanford, Ince, February 4), US. Department of Energy, Richland Operations Office, Richland, Washington. ${ }^{\mathrm{m}}$ Lenseigne, D. L. 1997, Tank Waste Remediation System Fiscal Year 1998 Multi-Year Program Plan, WBS. I, HNFF-SP-1230, prepared by Lockheed Martin Hanford. Corporation for Fluor Daniel Hanford, Inc., Richland, Washington. "FDH, 1997, Tank Waste Remediation System Basis for Interim Operation, HNF-SD-WM-BIO-001, Rev. 0, Fluor Daniel Hanford, Inc., Richland, Washington

P 10 CFR 61 , "Licensing Requirements for Land Disposal of Radioactive Waste, Code of Federal Regulations, as amended

$\begin{aligned} \mathrm{AP} & =\mathrm{AP} \text { Tank Farm. } \\ \mathrm{BIO} & =\text { Basis for Ynterin }\end{aligned}$

CFR $=$ Coste federal Reration.

DOE $=$ U.S. Department of Energy.

DE-HQ = U.S. Department of Energy-Headquarter.

$\mathrm{QO}=$ Data Quality Objectiv

$E A=$ Enabling Assumption

AMCS $=$ Enabling Assumptions Management Control Systen

Ecology $=$ Washington State Department of Ecolog

$\begin{aligned} \mathrm{ES} & =\text { environment } \\ \mathrm{FY} & \text { fiscal year. }\end{aligned}$

HLW = high-level waste.

$\triangle C D=$ Interface Control Document.

IHLW $=$ immobilized high-level waste.

LAW $=$ low-activity waste.

LLCE $=$ long-length contaminated equipment.

LMHC $=$ Lockheed Marth Hanford Corporation.

NEPA $=$ National En

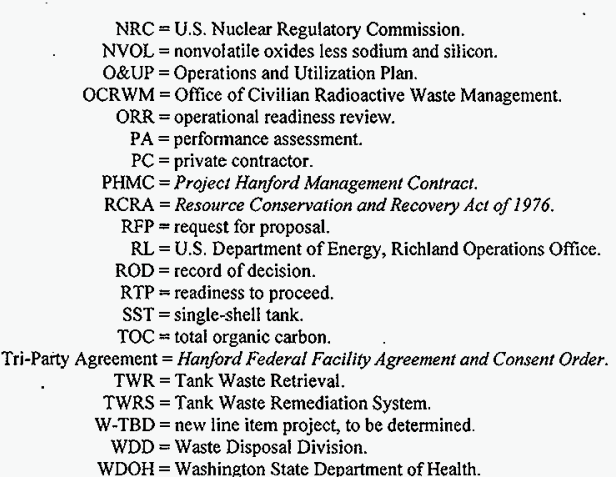

$\mathrm{NRC}=$ U.S. Nuclear Regulatory Commission.

(and

OCRWM $=$ Office of Civilian Radioactive Waste Management

$\mathrm{ORR}=$ operational readiness review.

$\begin{aligned} \mathrm{PA} & =\text { performance assessm } \\ \mathrm{PC} & =\text { privat } \\ & \end{aligned}$

PHMC $=$ Project Hanford Management Contract.
RCRA $=$ Resource Conservation and Recovery Act of 1976.

RFP $=$ request for proposal.

$\mathrm{RL}=$ U.S. Department of Energy, Richland Operations Office.

RTP $=$ readiness to proceed.

SST $=$ single-shell tank.

Tri-Party Agreement = Hanford Federal Facility Agreement and Consent Order.

TWR $=$ Tank Waste Retrieval.

TWRS $=$ Tank Waste Remediation System.

$W-1 B D=$ new line item project, to be delermined.

WDOH = Washington State Depar 


\subsection{INTEGRATION OF TANK WASTE REMEDIATION SYSTEM DATABASES}

The TWRS Project plans to merge Retrieval Mission and Disposal Key Assumptions and Key Risks into a common managed database. This database will be interconnected with the Requirements database already incorporated in the Hanford Site Technical Baseline Database.

\subsection{REFERENCES}

Acts

Clean Air Act of 1977, as amended, 42 U.S.C. 7401 , et seq.

National Environmental Policy Act of 1969, as amended, 42 USC 4321 et seq.

Resource Conservation and Recovery Act of 1976, as amended, 42 USC 6901 et seq.

\section{Federal Register}

62 FR 8693, 1997, "Record of Decision for the Tank Waste Remediation System, Hanford Site, Richland, WA" Federal Register, Vol. 62, pp. 8693-8704 (February 26).

\section{Code of Federal Regulations}

10 CFR 61, "Licensing Requirements for Land Disposal of Radioactive Waste," Code of Federal Regulations, as amended.

\section{Database}

EAMCS, n.d., Enabling Assumption Management and Control System, database maintained by Lockheed Martin Hanford Corporation for Fluor Daniel Hanford, Inc., Richland, Washington.

HSTD, n.d., Hanford Site Technical Baseline Database, database maintained by Lockheed Martin Hanford Corporation for Fluor Daniel Hanford, Inc., Richland, Washington. 
HNF-1945 Rev 0

\section{Logic Diagrams}

FDH, 1998, Logic Diagrams, prepared by Lockheed Martin Hanford Corporation for Fluor Daniel Hanford, Inc., Richland, Washington.

- H-2-823148, TWRS Retrieval Level 1 Logic Immobilized Waste (ILAW)

- H-2-829149, TWRS Retrieval Level 1 Logic Immobilized Waste (IHLW)

- H-2-829150, TWRS Retrieval Level 1 Logic Infrastructure Phase 1 Privatization Support

- H-2-892151, TWRS Retrieval Level 1 Logic Waste Feed Delivery LAW 1st Feed Batches Tank 241-AN-10.5

- H-2-829152, TWRS Retrieval Level 1 Logic Waste Feed Delivery LAW 2nd Feed Batches Tank 241-AN-104

- H-2-829153, TWRS Retrieval Level 1 Logic Waste Feed Delivery LAW 3rd Feed Batches Tank 241-AW-101

- H-2-829154, TWRS Retrieval Level 1 Logic Waste Feed Delivery LAW 4th Feed Batches Tank 241-AN-103

- H-2-829155, TWRS Retrieval Level 1 Logic Waste Feed Delivery LAW Sth Feed Batches Tanks 241-AP-101 \& 241-AW-104

- H-2-829156, TWRS Retrieval Level 1 Logic Waste Feed Delivery LAW 6th Feed Batches Tank 241-AY-101

- H-2-829157, TWRS Retrieval Level 1 Logic Waste Feed Delivery LAW 7th \& 8th Feed Batches Tank 241-AN-107

- H-2-829158, TWRS Retrieval Level 1 Logic Waste Feed Delivery LAW 9th Feed Batches Tank 241-AN-102

- H-2-829159, TWRS Retrieval Level 1 Logic Waste Feed Delivery LAW 10th Feed Batches Tank 241-AN-106

- H-2-829160, TWRS Retrieval Level 1 Logic Waste Feed Delivery LAW 11th Feed Batches Tank 241-SY-101

- H-2-829161, TWRS Retrieval Level 1 Logic Waste Feed Delivery LAW 12th Feed Batches Tank 241-SY-103

- H-2-829162, TWRS Retrieval Level I Logic Waste Feed Delivery HLW 1st \& 2nd Feed Batches First Tank, 241-AZ-101

- H-2-829163, TWRS Retrieval Level I Logic Waste Feed Delivery HLW 3rd \& 4th Feed Batches Second Tank, 241-AZ-102

- H-2-829164, TWRS Retrieval Level I Logic Waste Feed Delivery HLW 5th-9th Feed Batches Third Tank, 241-AY-102

- H-2-829165, TWRS Retrieval Level 1 Logic Waste Feed Delivery HLW 10th - 12th Feed Batches Fourth Tank, 241-C-104

- H-2-829166, TWRS Level 0 Logic (2 Sheets) 
HNF-1945 Rev 0

\section{Documents}

Acree, C. D., Jr., 1998, Tank Waste Remediation System Mission Analysis Report, HNF-SD-WM-MAR-008, Rev. 2, prepared by Lockheed Martin.Hanford Corporation for Fluor Daniel Hanford, Inc., Richland, Washington.

Acree, C. D., Jr., 1997, TWRS Technical Baseline Database Manager Definition Document, HNF-SD-TWR-CSUD-001, Rev. 0, prepared by Lockheed Martin Hanford Corporation, Richland, Washington.

Calmus, R. B., 1996, Design Requirements Document for Interim Storage Phase 1 Solidification of High-Level Waste, WHC-SD-WM-DRD-012, Westinghouse Hanford Company, Richland, Washington.

Claghorn, R. D., 1997, Decision Document for the Final Disposition for Cesium and Strontium Capsules, HNF-SD-WM-RPT-294, Rev. 0, prepared by Numatec Hanford Corporation for Fluor Daniel Hanford, Inc., Richland, Washington.

DOE, 1996, Draft Hanford Remedial Action Environmental Impact Statement and Comprehensive Land Use Plan, DOE/EIS-0222D, U.S. Department of Energy, Washington, D.C.

DOE, 1993, Justification of Mission Need, Hanford Site Tank Waste Remediation System to the Energy System Acquisition Advisory Board, U.S. Department of Energy, Washington, D.C.

DOE and Ecology, 1996, Tank Waste Remediation System, Hanford Site, Richland, Washington, Final Environmental Impact Statement, DOE/EIS-0189, U.S. Department of Energy and Washington State Department of Ecology, Washington, D.C.

Ecology, EPA, and DOE, 1996, Hanford Federal Facility Agreement and Consent Order, 2 vol., Washington State Department of Ecology, U.S. Environmental Protection Agency, and U.S. Department of Energy, Olympia, Washington.

Ecology and RL, 1995, Final Environmental Impact Statement, Safe Interim Storage of Hanford Tank Wastes, DOE/EIS-0212, Washington State Department of Ecology and U.S. Department of Energy, Richland Operations Office, Lacey, Washington.

FDH, 1997, Tank Waste Remediation System Basis for Interim Operation,

HNF-SD-WM-BIO-001, Rev. 0, prepared by Lockheed Martin Hanford Corporation for Fluor Daniel Hanford, Inc., Richland, Washington. 
HNF-1945 Rev 0

Freeman, D. V., 1998, Tank Waste Remediation System Program Plan, HNF-1883, Rev. 0, prepared by Lockheed Martin Hanford Corporation for Fluor Daniel Hanford, Inc., Richland, Washington.

Gneiting, B. C., 1996, RDD-100 Users' Guide for TWRS, WHC-SD-WM-CSUD-012, Rev. 0., Westinghouse Hanford Company, Richland, Washington.

Kirkbride, R.A., G. K. Allen, P. J. Certa, A. F. Manuel, R. M. Orme, L. W. Shelton, E. J. Slaathaug, R. S. Wittman, and G. T. MacLean, and D. L. Penwell, 1997, Tank Waste Remediation System Operation and Utilization Plan, HNF-SD-WM-SP-012, Rev. 0, Volumes I and II, prepared by Numatec Hanford Corporation for Fluor Daniel Hanford, Inc., Richland, Washington.

Kinzer, J. E., 1997, Contract Number DE-AC06-96RL13200; Tank Waste Remediation System (TWRS) System Requirements Review Action Plan, (letter 96-TWR-025 to H.J. Hatch, Fluor Daniel Hanford, Inc., February 4), U.S. Department of Energy, Richland Operations Office, Richland, Washington.

Lenseigne, D. L., 1997, Tank Waste Remediation System Fiscal Year 1998 Multi-Year Work Plan WBS 1.1, HNF-SP-1230, Rev. 0, prepared by Lockheed Martin Hanford Corporation for Fluor Daniel Hanford, Inc., Richland, Washington.

LMHC, 1997, TWRS Administration, HNF-IP-0842, Fluor Daniel Hanford, Inc., Richland, Washington.

Mickle, G. D., 1995, Tank Farm Health and Safety Plan, WHC-SD-WM-HSP-002, Rev. 2, Westinghouse Hanford Company, Richland, Washington.

Noorani, Y. G., 1997, Tank Waste Remediation System Technical Safety Requirements, HNF-SD-WM-TSR-006, Rev. 0, prepared by DE\&S Hanford, Inc. for Fluor Daniel Hanford, Inc., Richland, Washington.

Papp, I. G., 1997, Waste Feed Delivery Technical Basis Document, HNF-1939, DRAFT, Vol.III, prepared by Numatec Hanford corporation for Fluor Daniel Hanford, Inc., Richland, Washington.

Papp, I. G., 1997, Technical Baseline Description of High-Level Waste and Low-Activity Waste Feed Mobilization and Delivery, HNF-SD-TWR-TM-001, Rev. 0, prepared by Numatec Hanford Corporation for Fluor Daniel Hanford Inc., Richland, Washington.

Peck, L.G., 1998, Tank Waste Remediation System Systems Engineering Management Plan, HNF-SD-WM-SEMP-002, Rev. 1, prepared by Lockheed Martin Hanford Corporation for Fluor Daniel Hanford, Inc., Richland, Washington. 
Potter, R. D., and R. L. Treat, 1998, Tank Waste Remediation System Retrieval and Disposal Mission Waste Feed Delivery Plan, HNF-1881, Rev. 0, prepared by Lockheed Martin Hanford Corporation for Fluor Daniel Hanford, Inc., Richland, Washington.

RL, 1997, Hanford Site Environmental Management Specification, DOE/RL-97-55, U.S. Department of Energy, Richland Operations Office, Richland, Washington.

RL, 1996a, British Nuclear Fuels Laboratory Privatization Contract, DE-AC06-96RL13308, U.S. Department of Energy, Richland Operations Office, Richland, Washington.

RL, 1996b, Hanford Strategic Plan, DOE/RL 96-92, Rev. 0, U.S. Department of Energy, Richland Operations Office, Richland, Washington.

RL, 1996c, Lockheed Martin Advanced Environmental Systems Privatization Contract, DE-AC06-96RL13309, U.S. Department of Energy, Richland Operations Office, Richland, Washington.

Root R. W., Jr., and R. D. Potter, 1998, Tank Waste Remediation System Retrieval and Disposal Mission Infrastructure Plan, HNF-1882, Rev. 0, prepared by Lockheed Martin Hanford Corporation for Fluor Daniel Hanford, Inc., Richland, Washington.

Taylor, W. J., 1997, Contract Number DE-AC06-96RL13200 Waste Disposal Division MYWP Guidance for FY 1998, (letter 97-WDD-128 to H. J. Hatch and A. M. Umek, Fluor Daniel Hanford, Inc., August 6) U.S. Department of Energy, Richland Operations Office, Richland, Washington.

Taylor, W. J., 1997, Subcontract 80232764-9-K001, DOE/RL DST Integrity Assessment Work Planning, (letter 97-WSD-232 to H. J. Hatch and A. M. Umek, Fluor Daniel Hanford, Inc., October 30) U.S. Department of Energy, Richland Operations Office, Richland, Washington.

Umek, A. M., and D. S. Rewinkle, 1997, Subcontract 80232764-9-K001, DOE/RL DST Integrity Assessment Work Planning, (letter 9760373A to L. E. Hall, Lockheed Martin Hanford Corporation, November 25) Fluor Daniel Hanford, Inc., Richland, Washington.

Vann, J. M., E. R. Hamm, and R. D. Crisp, 1998, Tank Waste Remediation System Configuration Management Plan, HNF-1900, Rev. 0, prepared by Lockheed Martin Hanford Corporation for Fluor Daniel Hanford, Inc., Richland, Washington. 
HNF-1945 Rev 0

This page intentionally left blank. 
HNF-1945 Rev 0

APPENDIX A

GUIDANCE AND REQUIREMENTS TO

DELIVERABLES CROSSWALK

TWRS Retrieval and Disposal Mission

Key Enabling Assumptions 
HNF-1945 Rev 0

This page intentionally left blank. 
Table A-1. Guidance and Requirements to Deliverables Crosswalk - TWRS Retrieval and Disposal Mission Key Enabling Assumptions..

\begin{tabular}{|c|c|c|}
\hline Guidance or Requirement & Status & Implementing Location \\
\hline 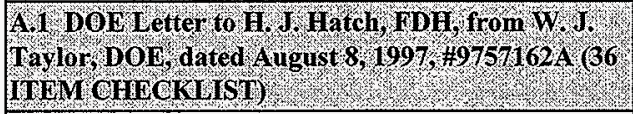 & & 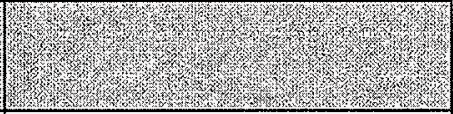 \\
\hline $\begin{array}{l}\text { 6. All enabling assumptions have been formally } \\
\text { documented. Assumptions which have been replaced } \\
\text { with facts or decisions have been changed in } \\
\text { requirements documentation. }\end{array}$ & I & Entire Document. (HNF-1945) \\
\hline $\begin{array}{l}\text { 10. Interface control documents have been prepared, } \\
\text { DOE comments have been resolved, issues have been } \\
\text { addressed, and approved interfaces are managed. }\end{array}$ & I & Key Enabling Assumptions 8 \& 9 \\
\hline $\begin{array}{l}\text { 16. The technical baseline is complete and defensible, } \\
\text { and represents best value to the government. }\end{array}$ & I & $\begin{array}{l}\text { Entire Document; Enabling } \\
\text { Assumptions were taken from the } \\
\text { technical baseline reviews. }\end{array}$ \\
\hline 24. Activities have been properly funded. & I & Key Enabling Assumption 10 \\
\hline $\begin{array}{l}\text { 26. There is agreement among scope, budget, and } \\
\text { schedule. The scope of work can be performed within } \\
\text { budget and on schedule. }\end{array}$ & I & $\begin{array}{l}\text { Key Enabling Assumptions } 1 \text { through } \\
37\end{array}$ \\
\hline $\begin{array}{l}\text { 35. A risk and decision management program has } \\
\text { been implemented at all levels. }\end{array}$ & I & Entire Document. (HNF-1945) \\
\hline 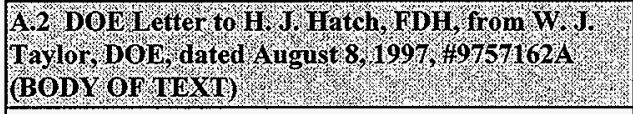 & & \\
\hline \multicolumn{3}{|l|}{$\begin{array}{l}\text { Specific Responsibility from RL's August } 8,1997 \\
\text { letter, Section } 2.2\end{array}$} \\
\hline $\begin{array}{l}\text { 1. Waste feed can be provided in the specified amount } \\
\text { to the specified place at the specified time }\end{array}$ & I & $\begin{array}{l}\text { Key Enabling Assumptions } 1,3,4,8 \\
9,10,12,13,14,16,23,25,27,28,30 \\
34,35,36, \text { and } 37\end{array}$ \\
\hline \multicolumn{3}{|l|}{ 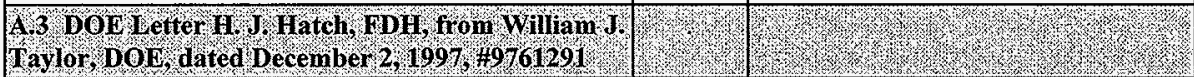 } \\
\hline $\begin{array}{l}\text { 9. Identify the decisions that are being deferred, when } \\
\text { they are projected to be finalized and the assumptions } \\
\text { relating to those decisions. }\end{array}$ & I & Entire Document. (HNF-1945) \\
\hline C.1. Interface Controldoocuments & 4 & \\
\hline 14. Immobilized High-Level Waste & & \\
\hline
\end{tabular}


Table A-1. Guidance and Requirements to Deliverables Crosswalk - TWRS Retrieval and Disposal Mission Key Enabling Assumptions..

\begin{tabular}{|c|c|c|}
\hline Guidance or Requirement & Status & Implementing Location \\
\hline $\begin{array}{l}\text { 1. Provide clean, approved shipping containers } \\
\text { delivered to the Contractor-designated transfer facility. } \\
\text { Shipping containers will be provided in accordance } \\
\text { with the following: }\end{array}$ & I & $\begin{array}{l}\text { Addressed in other enabling } \\
\text { assumptions (not "Key") }\end{array}$ \\
\hline \multicolumn{3}{|l|}{ 15. Immobilized Low-Activity Waste } \\
\hline 2. Accept the ILAW product. & I & $\begin{array}{l}\text { Key Enabling Assumptions 20, 22, 31, } \\
33 \text {, and } 37\end{array}$ \\
\hline 19. Low-Activity Waste Feed & . & . \\
\hline $\begin{array}{l}\text { 2. Provide tank waste feed composition prior to } \\
\text { transfer to the Contractor's waste feed tank (AP- } 106 \text { or } \\
\mathrm{AP}-108 \text { ) and provide the information to the Contractor. }\end{array}$ & I & $\begin{array}{l}\text { Key Enabling Assumptions 11, 36, and } \\
37\end{array}$ \\
\hline $\begin{array}{l}\text { 3. Transfer waste feed to the Contractor in accordance } \\
\text { with Clause H.9, Ordering and Contract Order } \\
\text { Quantities. }\end{array}$ & I & $\begin{array}{l}\text { Key Enabling Assumptions 12, 14, and } \\
16\end{array}$ \\
\hline \multicolumn{3}{|l|}{ 20. High-Level Waste Feed } \\
\hline $\begin{array}{l}\text { 3. Transfer the waste feed to the Contractor in } \\
\text { accordance with Clause H.9, Ordering and Contract } \\
\text { Order Quantities. }\end{array}$ & I & $\begin{array}{l}\text { key Enabling Assumptions } 12,14 \text {, and } \\
16\end{array}$ \\
\hline 21. Waste Feed Tanks & $\mathrm{I}$ & $\begin{array}{l}\text { Key Enabling Assumptions 5,6,7, and. } \\
28\end{array}$ \\
\hline \multicolumn{3}{|l|}{$\begin{array}{l}\text { D1 Detailed lostructions for A ssessment of RTP } \\
\text { Appendix C, November } 14,1997\end{array}$} \\
\hline $\begin{array}{l}\text { 1. Show the ability to provide HLW and LAW waste } \\
\text { feed at the correct rate to the correct location with } \\
\text { verified composition and carry out responsibilities per } \\
\text { the following ICDs: }\end{array}$ & I & $\begin{array}{l}\text { Key Enabling Assumptions 12, 14, 16, } \\
\text { and } 33\end{array}$ \\
\hline $\begin{array}{l}\text { 6. Identify those activities most at risk for meeting the } \\
\text { June, } 2002 \text { hot start }\end{array}$ & $\mathrm{I}$ & Entire Document (HNF-1945) \\
\hline $\begin{array}{l}\text { 9. Show the ability of the PHMC Team to turnover } \\
\text { waste feed tanks AP-106 and } 108 \text { to private contractors } \\
\text { per ICD-21. }\end{array}$ & 1 & $\begin{array}{l}\text { Key Enabling Assumptions 5, 6, 7, and } \\
28\end{array}$ \\
\hline $\begin{array}{l}\text { 13. Discuss the likelihood that projects will require } \\
\text { revalidation based on changes in requirements created } \\
\text { by private contractor's ICDs/deliverables. }\end{array}$ & I & Key Enabling Assumption 9 \\
\hline $\begin{array}{l}\text { 20. Describe the overall risk of proceeding with } \\
\text { Phase } 1 \mathrm{~B} \text {, individual risks, and risk handling actions } \\
\text { for each. }\end{array}$ & I & Entire Document (HNF-1945) \\
\hline
\end{tabular}


Table A-1. Guidance and Requirements to Deliverables Crosswalk - TWRS Retrieval and Disposal Mission Key Enabling Assumptions..

\begin{tabular}{|c|c|c|}
\hline Guidance or Requirement & Status & Implementing Location \\
\hline $\begin{array}{l}\text { 21. Show that the PHMC Team is on schedule for } \\
\text { completing safety-related documents supporting the } \\
\text { private contractor(s). }\end{array}$ & I & $\begin{array}{l}\text { Key Enabling Assumptions 10, 18, 21, } \\
\text { and } 23\end{array}$ \\
\hline $\begin{array}{l}\text { 30. Show that the PHMC Team is on schedule for } \\
\text { completing regulatory-compliance-related documents } \\
\text { supporting the private contractor(s). }\end{array}$ & $\mathrm{I}$ & $\begin{array}{l}\text { Key Enabling Assumptions 15, 17, 19, } \\
\text { and } 24\end{array}$ \\
\hline $\begin{array}{l}\text { D. } 2 \text { plan for Determining pHMe teams RT for } \\
\text { Waste Fed Delivery (Table 2). }\end{array}$ & 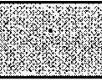 & 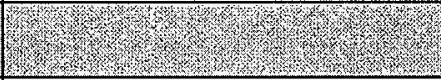 \\
\hline $\begin{array}{l}\text { PHMC provide deliverables necessary to support RTP, } \\
\text { as follows: }\end{array}$ & & \\
\hline 27. Licensing Strategy & I & $\begin{array}{l}\text { Key Enabling Assumptions 15, 17, 19, } \\
\text { and } 22\end{array}$ \\
\hline 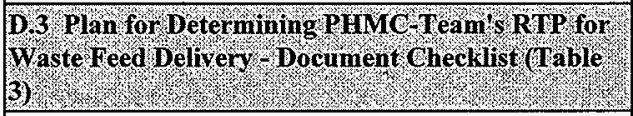 & & W \\
\hline $\begin{array}{l}\text { 1. Plans call for providing envelope } \mathrm{A}, \mathrm{B} \text {, and } \mathrm{C} \text { waste } \\
\text { to the privatization contractors within } 60 \text { days of } \\
\text { request in the amount assumed in TWRS process } \\
\text { flowsheet per paragraph } 2.2 .2 .6 \text {. }\end{array}$ & I & $\begin{array}{l}\text { Key Enabling Assumptions 11, 14, 16, } \\
34,36 \text {, and } 37\end{array}$ \\
\hline $\begin{array}{l}\text { 2. Plans call for implementing sludge-washing } \\
\text { capability to provide sludge to privatization } \\
\text { contractor(s) in Phase 1B. }\end{array}$ & I & Key Enabling Assumptions 27 \\
\hline $\begin{array}{l}\text { 3. Plans call for retrieving DST waste to make room } \\
\text { for SST waste, to optimize tank storage, and to stage } \\
\text { waste. }\end{array}$ & I & $\begin{array}{l}\text { key Enabling Assumptions 25, 28, 29, } \\
\text { and } 35\end{array}$ \\
\hline $\begin{array}{l}\text { 5. Plans include demonstrating past-practice-sluicing } \\
\text { technology. }\end{array}$ & I & $\begin{array}{l}\text { Addressed in other Enabling } \\
\text { Assumptions (not "Key") }\end{array}$ \\
\hline $\begin{array}{l}\text { 19. Plans include tank sampling and analysis from } \\
2003 \text { through } 2011 \text {. }\end{array}$ & I & $\begin{array}{l}\text { Key enabling Assumptions } 11,36 \text {, and } \\
37\end{array}$ \\
\hline $\begin{array}{l}\text { 30. Plans are for the 242-A evaporator to be supplied } \\
\text { by the Liquid Effluents Program to support ops until } \\
\text { the immobilization facilities are in operation. }\end{array}$ & I & $\begin{array}{l}\text { Addressed in other Enabling } \\
\text { Assumptions (not "Key") }\end{array}$ \\
\hline $\begin{array}{l}\text { 31. Plans are for upgrades to the evaporator needed to } \\
\text { extend ops. to } 2011 \text { to occur by } 2005 \text {. }\end{array}$ & I & Key Enabling Assumption 29 \\
\hline $\begin{array}{l}\text { 35. Plans conclude that two-300-HP mixers will be } \\
\text { sufficient to mobilize sludge in each DST. }\end{array}$ & I & Key Enabling Assumption 30 \\
\hline
\end{tabular}


Table A-1. Guidance and Requirements to Deliverables Crosswalk - TWRS Retrieval and Disposal Mission Key Enabling Assumptions..

\begin{tabular}{|c|c|c|}
\hline Guidance or Requirement & Status & Implementing Location \\
\hline $\begin{array}{l}\text { 40. Plans are that during and after } 2002, \mathrm{DOE} \text { will pay } \\
\text { for one sampling and analysis of each waste envelope } \\
\text { batch; Additional sampling and analyses will be at the } \\
\text { private contractor's expense. }\end{array}$ & I & $\begin{array}{l}\text { Addressed in other enabling } \\
\text { assumptions (not "Key") }\end{array}$ \\
\hline $\begin{array}{l}\text { 58. Plans describe reassessing the timing and needs } \\
\text { for procurement of additional mixer pumps for DSTs, } \\
\text { considering the need dates and availability of advanced } \\
\text { mixer-pump designs. }\end{array}$ & $\mathrm{I}$ & Key Enabling Assumption 30 \\
\hline $\begin{array}{l}\text { 59. Plans describe evaluation of the sludge-washing } \\
\text { process as required by TPA M-50-03 (Completed). }\end{array}$ & I & Key Enabling Assumption 27 \\
\hline $\begin{array}{l}\text { 64. Plans include meeting feed quantity requirements } \\
\text { for Phase } 1 \text { and allowing the HTI heel demonstration } \\
\text { to proceed. }\end{array}$ & I & $\begin{array}{l}\text { Key Enabling Assumptions } 1,3,4,8 \text {, } \\
9,10,12,13,14,16,23,25,27,28,30 \\
34,35,36 \text {, and } 37\end{array}$ \\
\hline $\begin{array}{l}\text { 65. Plans include completing design activities and } \\
\text { safety studies to support installation of the mixer } \\
\text { pumps in AP-102, } 104 \text { and } 105 \text { and determine the } \\
\text { needs for all tanks identified in the Phase } 1 \text { feed. }\end{array}$ & I & Key Enabling Assumption 30 \\
\hline 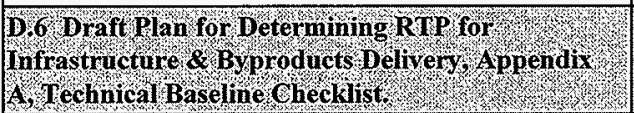 & & \\
\hline $\begin{array}{l}\text { 22. Validation of enabling assumptions and planning } \\
\text { document update is scheduled, funded, proceduralized } \\
\text { and/or managed. (6.1.1-6.1.2) }\end{array}$ & $\mathrm{I}$ & Entire Document (HNF-1945) \\
\hline 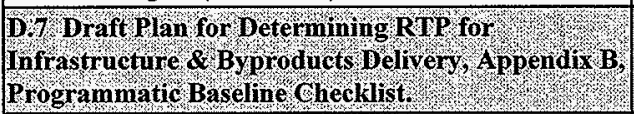 & & \\
\hline $\begin{array}{l}\text { 35. Provide schedule risks and identify how schedules } \\
\text { are managed to reduce risk. }(2.5 .1-2.5 .7)\end{array}$ & I & Entire Document (HNF-1945) \\
\hline $\begin{array}{l}\text { D8 Draft Plan for Deternining RTP for } \\
\text { Infrastructure \& Byproducts Delivery Appendix } \\
\text { C. Infrastructure (Nanagement Baseline) } \\
\text { Checklist }\end{array}$ & & \\
\hline $\begin{array}{l}\text { 45. Show acceptable environmental permits and safety } \\
\text { bases are in place. }(1.3 .1-1.3 .2)\end{array}$ & $\mathrm{I}$ & $\begin{array}{l}\text { Addressed in other enabling } \\
\text { assumptions (not "Key") }\end{array}$ \\
\hline 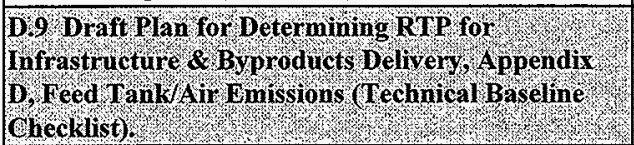 & & \\
\hline
\end{tabular}


Table A-1. Guidance and Requirements to Deliverables Crosswalk - TWRS Retrieval and Disposal Mission Key Enabling Assumptions..

\begin{tabular}{|c|c|c|}
\hline Guidance or Requirement & Status & Implementing Location \\
\hline $\begin{array}{l}\text { 66. Validation of enabling assumptions and planning } \\
\text { document update is scheduled, funded, proceduralized } \\
\text { and/or managed. (6.1.1-6.1.2) }\end{array}$ & I & Entire Document (HNF-1945) \\
\hline 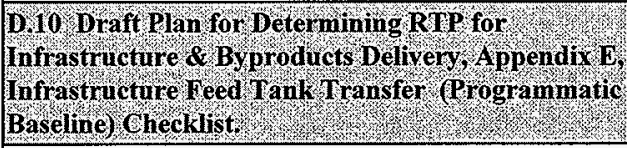 & & \\
\hline $\begin{array}{l}\text { 79. Provide schedule risks and identify how schedules } \\
\text { are managed to reduce risk. }(2.5 .1-2.5 .7)\end{array}$ & I & Entire Document (HNF-1945) \\
\hline 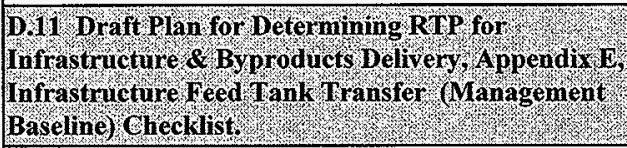 & & \\
\hline $\begin{array}{l}\text { 89. Show acceptable environmental permits and safety } \\
\text { bases are in place. }(1.3 .1-1.3 .2)\end{array}$ & $I$ & $\begin{array}{l}\text { Addressed in other enabling } \\
\text { assumptions (not "Key") }\end{array}$ \\
\hline 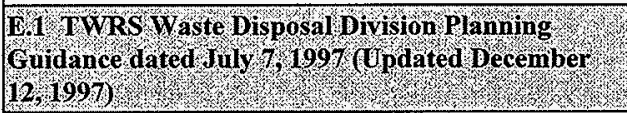 & & \\
\hline Mandatory completion of approved TPA milestones. & $\mathrm{I}$ & Key Enabling Assumption 24 \\
\hline $\begin{array}{l}\text { Division will assume responsibility for TWRS Waste } \\
\text { Storage program beginning in } 2002 \text { and Management } \\
\text { Systems functions in fiscal year } 2006 \text {. }\end{array}$ & I & $\begin{array}{l}\text { Key Enabling Assumptions 2,3,4, } \\
\text { and } 12\end{array}$ \\
\hline $\begin{array}{l}\text { Waste Processing will make the Phase } 1 \text { assumptions } \\
\text { outlined in paragraph 3.3.2.1. }\end{array}$ & I & $\begin{array}{l}\text { Key Enabling Assumptions 8, 27, 31, } \\
32 \text {, and } 33\end{array}$ \\
\hline
\end{tabular}


HNF 1945 Rev 0

This page intentionally left blank. 


\section{DISTRIBUTION SHEET}

\begin{tabular}{|c|c|c|c|c|c|}
\hline \multirow{2}{*}{$\begin{array}{l}\text { To } \\
\text { Document Control Services }\end{array}$} & From & & & \multicolumn{2}{|l|}{ Page 1 of 1} \\
\hline & \multicolumn{3}{|c|}{ TWRS Configuration Management } & \multicolumn{2}{|c|}{ Date January 3, 1998} \\
\hline \multirow{2}{*}{\multicolumn{4}{|c|}{$\begin{array}{l}\text { Project Tit]e/Work Order } \\
\text { Tank Waste Remediation Systems (HNF-1945) }\end{array}$}} & \multirow{2}{*}{\multicolumn{2}{|c|}{$\begin{array}{l}\text { EDT No. } 6092724-6274-8 \\
\text { ECN No. }\end{array}$}} \\
\hline & & & & & \\
\hline Name & MSIN & $\begin{array}{l}\text { Text } \\
\text { With All } \\
\text { Attach. }\end{array}$ & $\begin{array}{l}\text { Text } \\
\text { Only }\end{array}$ & $\begin{array}{l}\text { Attach./ } \\
\text { Appendix } \\
\text { On } 7 y\end{array}$ & $\begin{array}{c}\text { EDT/ECN } \\
\text { Only }\end{array}$ \\
\hline
\end{tabular}

C.D. Acree, Jr

J.N. Alibert

P.R. Anglier

H.L. Boston

M.P. Delozier

M.D. Ebben

J.E. Ferguson

K.A. Gasper

M.L. Grygiel

J.O. Honeyman

R.A. Kirkbride

S.C. Klimper

E.E. Mayer

D.M. McDanie 1

R.J. Murkowski

S.M. O'Toole

M.A. Payne

L.G. Peck

M.L. Peterman

R.W. Powell

R.E, Raymond

S.H. Rifaey

B. Root

P.S. Schaus

S.E. Seeman

S.J. Simon

R.L. Treat

J.M. Vann

J.H. Wicks Jr

R.D. Wojtasek

B.D. Zimmerman
K.N. Jordan

\begin{tabular}{|c|c|}
\hline $\mathrm{H} 6-35$ & $x$ \\
\hline $52-48$ & $x$ \\
\hline$\$ 7-82$ & $x$ \\
\hline G3-21 & $x$ \\
\hline$R 2-58$ & $x$ \\
\hline $\mathrm{H} 7-07$ & $x$ \\
\hline H8-71 & $x$ \\
\hline $\mathrm{H} 6-37$ & $x$ \\
\hline H8-71 & $x$ \\
\hline G3-21 & $x$ \\
\hline G3-21 & $x$ \\
\hline $\mathrm{H} 5-27$ & $x$ \\
\hline$H 6-25$ & $x$ \\
\hline$R 2-36$ & $x$ \\
\hline $\mathrm{H} 7-06$ & 3 copies \\
\hline $\mathrm{H} 6-37$ & $x$ \\
\hline G3-21 & $x$ \\
\hline$R 2-58$ & $x$ \\
\hline$H 6-35$ & 4 copies \\
\hline H7-06 & $x$ \\
\hline $\mathrm{H} 5-03$ & $x$ \\
\hline R2-38 & $x$ \\
\hline R1-56 & $x$ \\
\hline G3-21 & $x$ \\
\hline $\mathrm{H} 5-03$ & $x$ \\
\hline$H 6-35$ & $x$ \\
\hline $\mathrm{H} 7-06$ & $x$ \\
\hline H5-03 & $x$ \\
\hline $46-37$ & $x$ \\
\hline $\mathrm{H} 7-07$ & $x$ \\
\hline G3-21 & $x$ \\
\hline H6-35 & 10 copies \\
\hline
\end{tabular}

Central Files

B 7-07 $x$ 